Louisiana State University

LSU Digital Commons

$2-20-2017$

\title{
Geochemical evidence for initiation of the modern Mekong delta in the southwestern South China Sea after $8 \mathrm{Ma}$
}

\author{
Chang Liu \\ Louisiana State University \\ Peter D. Clift \\ Louisiana State University \\ Richard W. Murray \\ Boston University \\ Jerzy Blusztajn \\ Woods Hole Oceanographic Institution \\ Thomas Ireland \\ Boston University
}

See next page for additional authors

Follow this and additional works at: https://digitalcommons.Isu.edu/geo_pubs

\section{Recommended Citation}

Liu, C., Clift, P., Murray, R., Blusztajn, J., Ireland, T., Wan, S., \& Ding, W. (2017). Geochemical evidence for initiation of the modern Mekong delta in the southwestern South China Sea after $8 \mathrm{Ma}$. Chemical Geology, 451, 38-54. https://doi.org/10.1016/j.chemgeo.2017.01.008

This Article is brought to you for free and open access by the Department of Geology and Geophysics at LSU Digital Commons. It has been accepted for inclusion in Faculty Publications by an authorized administrator of LSU Digital Commons. For more information, please contact ir@lsu.edu. 


\section{Authors}

Chang Liu, Peter D. Clift, Richard W. Murray, Jerzy Blusztajn, Thomas Ireland, Shiming Wan, and Weiwei Ding 
1 Geochemical Evidence for Initiation of the Modern Mekong Delta in

2 the southwestern South China Sea after $8 \mathrm{Ma}$

4 Chang Liu ${ }^{1}$, Peter D. Clift ${ }^{1 *}$, Richard W. Murray $^{2}$, Jerzy Blusztajn $^{3}$, Thomas Ireland ${ }^{2}$, Shiming

$5 \quad$ Wan $^{4}$, Weiwei Ding 5

6

71 - Department of Geology and Geophysics, Louisiana State University, Baton Rouge 70803, USA

82 - Department of Earth and Environment, Boston University, Boston, MA 02215, USA

93 - Department of Geology and Geophysics, Woods Hole Oceanographic Institution, Woods Hole, MA 10 02540, USA

114 - Key Laboratory of Marine Geology and Environment, Institute of Oceanology, Chinese Academy of

12 Sciences, Qingdao 266071, China

135 - The Second Institute of Oceanography, State Oceanic Administration, Hangzhou 310012, China

14

15 Abstract

Sedimentary records in the southwestern South China Sea reflect the evolving erosion

17 and drainage systems that have operated in Southeast Asia during the Neogene. Analyses of the

18 chemistry and clay mineral composition of sediments from International Ocean Discovery

19 Program (IODP) Site U1433 allow us to examine these processes over the last 17 Ma. Sediment

* Corresponding author: pclift@1su.edu 
20 older than $8 \mathrm{Ma}$ was deposited relatively slowly. $\mathrm{Sr}$ and $\mathrm{Nd}$ isotopes indicate a variable

21 provenance with sequences of less and more altered material accompanied by strong changes in

22 the proportion of smectite. Sediment flux was probably from Indochina, as well as from a more

23 primitive volcanic source, most likely the Palawan ophiolite and/or Luzon. Sediments younger

24 than 8 Ma show a more stable $\mathrm{Sr}$ and $\mathrm{Nd}$ isotope character, indicating sources close to those seen

25 in the modern Mekong River, although with some influx from smaller rivers draining the

26 Indochina margin especially from 4-8 Ma. Our data are consistent with seismic estimates for an

27 onset to the Mekong in its present location after $8 \mathrm{Ma}$, following an avulsion from the Gulf of

28 Thailand.

30 Keywords: Geochemistry; clay minerals; isotopes; provenance

\section{Introduction}

Erosion and chemical weathering are primary processes that drive recycling of the continental

34 crust and the generation of the sedimentary record (Clift et al., 2009; McLennan, 1993).

35 Nonetheless, debate continues concerning what factors are most influential in controlling erosion

36 and weathering and how quickly these respond to tectonic and climatic forcing (Burbank et al.,

37 2003; Lavé and Avouac, 2001; Liu et al., 2005; Riebe et al., 2001; Wobus et al., 2010). Southeast

38 Asia is a good location to investigate such issues because of the strong forcing of the East Asian

39 monsoon, which dominates the climate of the area. Much of the sediment that has been eroded

40 from the Asian continent, some from the edge of the Tibetan Plateau, is delivered into the South

41 China Sea by a number of small and well-known larger river systems, including the Pearl, Red, 
42 and Mekong (Fig. 1). This has resulted in the accumulation of large volumes of sediment around

43 the continental margins of the South China Sea (Métivier et al., 1999).

44 Sediment provenance and delivery rates are complicated by the fact that there has been

45 substantial drainage reorganization in Southeast Asia, probably driven by the progressive uplift

46 of Asian topography, which has resulted in head water capture and the diversion of river systems

47 into different parts of the continental margin during the Cenozoic (Clark et al., 2004; Clift et al.,

48 2006a; Zheng et al., 2013). Unless the changing source of sediment can be deciphered, using

49 reconstructions of chemical weathering to infer continental environmental change is potentially

50 unreliable because varying source compositions may overprint the effects of the climatically

51 driven weathering.

52 In this study we examined sediment from a new scientific drilling site in the central

53 southwestern part of the deep-water basin (Fig. 1) and attempted to reconstruct both the sources

54 of the sediment since $\sim 17 \mathrm{Ma}$, and to assess the varying degrees of chemical weathering, in order

55 to understand how tectonism and changing climate may have impacted the sediment of the deep-

56 water basin, as well as environmental conditions in the source regions.

\subsection{Geological Setting}

Our study exploits sediment cored at International Ocean Discovery Program (IODP) Site U1433 (Li et al., 2015), located in the southwestern part of the South China Sea basin. The South

61 China Sea itself initially began to extend in the latest Cretaceous (Cullen et al., 2010), but

62 underwent the main phase of continental rifting in the Eocene (Ru and Pigott, 1986; Su et al.,

63 1989), culminating in the onset of seafloor spreading around $30 \mathrm{Ma}$ (Briais et al., 1993). Study of

64 paleomagnetic data has resulted in a debate about when active seafloor spreading ceased 
(Barckhausen et al., 2014), but drilling during IODP Expedition 349 now demonstrates that this

66 finished at $15-16 \mathrm{Ma}$ (Li et al., 2014). Site U1433 overlies an oceanic basaltic basement dated at $\sim 17 \mathrm{Ma}$ (Li et al., 2015), and seafloor spreading in the basin finished shortly after the eruption of this basement.

The causes of the extension itself have been widely debated and have involved relative shear between Indochina and mainland China as a result of the left lateral extrusion of Indochina along the Red River Fault Zone (Replumaz and Tapponnier, 2003; Tapponnier et al., 1982). Alternatively, others have invoked subduction-related forces towards the south, causing the 
implicated as the primary source to Ocean Drilling Program (ODP) Site 1143, which is located only $\sim 450 \mathrm{~km}$ to the southeast (Wan et al., 2006)(Fig. 1). This largely reflects the substantial discharge from the Mekong, 166 mT/yr (Milliman and Syvitski, 1992) and also the fact that other potential sources, such as Luzon or Borneo, are isolated from the site by significant bathymetric features such as the Manila Trench and the Sabah Trough (Fig. 1). However, estimated average annual discharge of $~ 459$ and $498 \mathrm{mT} / \mathrm{yr}$ respectively from North Borneo and from Sumatra (Milliman et al., 1999) raises the possibility that these may have been important sources in the past. However, because these values are modeled, not measured, they may be over-estimates, as implied by more recent estimates of $\sim 30 \mathrm{mT} / \mathrm{yr}$ for the Rajang River, the largest in northern Borneo (Milliman and Farnsworth, 2011). Furthermore, seafloor samples north of Reed Bank ( $190 \mathrm{~km}$ to the east of the site), have relatively primitive $\varepsilon_{\mathrm{Nd}}$ values (3.1)(Wei et al., 2012) and >40\% smectite contents suggestive of dominant supply from Luzon (Liu et al., 2016b) in recent times.

We were interested to test the concept that the Mekong River had a relatively recent initiation. A secondary objective was to test the erosional and weathering response within the Mekong basin of changes in monsoon intensity since the beginning of the Middle Miocene.

104 Seismic data collected close to the Vietnamese coast, as well as on the continental margin, 105 
111 time and spanning the entire basin history. The sediments overlying the basement are almost 800

$112 \mathrm{~m}$ thick and are dominated by massive and bioturbated muds and mudstones, largely clays, but

113 with a significant proportion of fine silt which are interpreted as turbidites. These sediments are

114 interbedded with graded calcareous turbidites, at least until the upper $250 \mathrm{~m}$ of the section

115 (Pleistocene) where mudstones dominated entirely (Fig. 2)(Li et al., 2015). At the microscopic

116 level, the clay-rich sediment are seen to contain minor but significant quantities of opaque

117 material and fine silt-sized quartz, as well as some lithic grains, chert and feldspar. Fragments of

118 angular, mafic, volcanic glass are also observed at very low concentrations. The bulk of the

119 intercalated sediment is redeposited carbonate, likely derived from the reef areas of the

120 Dangerous Grounds and the Reed Bank to the south. Over some intervals carbonate dominates,

121 but we only focus on the clastic fraction. Over the basal $49 \mathrm{~m}$ of the section the sediment is a 122 reddish brown claystone with very minor silt and no calcareous microfossils in a deposit similar 123 to those seen in the central Pacific basin.

\subsection{Sediment Provenance in the South China Sea}

In order to reconstruct erosion patterns and changes in sediment supply we first need to

127 identify specific characteristics that allow us to assign clastic sedimentary particles to particular

128 bedrock sources, something which is possible in Southeast Asia as a result of the diversity of

129 possible source terrains that surround the South China Sea (Clift, 2015). The ability to

130 distinguish and estimate the amount of sediment derived from a given source is based on the

131 concept that the bedrock sources providing the sediment differ from one another, either in terms 
132 of their chemistry, geochronology or tectonic evolution. These differences are then transferred

133 from the bedrock to the sediment in the rivers and thus to the offshore.

134

135

136

137

138

139

140

141

142

143

144

145

The tectonic blocks of SE Asia were largely brought into juxtaposition during the Triassic Indosinian Orogeny (Carter et al., 2001; Lepvrier et al., 2004). Because of their contrasting geological histories, the various tectonic blocks produce sediment of different composition, which can then be detected in the sediments deposited at Site U1433. The geological evolution of each of these blocks is relatively complicated, but in general southern China (Cathaysia), represents a tectonic block that collided with the Yangtze Craton $\sim 800 \mathrm{Ma}$ and later was the host to a Mesozoic volcanic arc complex (Fletcher et al., 2004; Jahn et al., 1990). Other tectonic blocks were rifted from Gondwana and accreted to Asia largely during the Triassic (Metcalfe, 1996). These have been later overprinted by younger events, although the old age of the basement has remained undisturbed. Consideration of radiogenic isotopes, especially $\mathrm{Sr}$ and $\mathrm{Nd}$, in the rivers of Southeast Asia suggests that there are resolvable differences between the large blocks draining the Pearl, Red and Mekong Rivers (Liu et al., 2007).

An alternative approach to provenance may involve consideration of the bulk sediment geochemistry and clay mineral assemblages, which are known to be different in different parts the South China Sea. Chemical weathering intensity is generally high in the tectonically inactive Pearl River basin and is less pronounced in the Mekong and lower still in the Red River (Liu et al., 2007). Chemical weathering is also high in the Malay Peninsula and in Sumatra (Liu et al., 2012). In the present day certain source terranes are associated with high concentrations of particular clay minerals. Erosion of the volcanic terrains in Luzon in the Philippines is marked by high concentrations of smectite (Liu et al., 2009b), whereas erosion from Taiwan is marked by sediment rich in illite and chlorite (Liu et al., 2008). Kaolinite is associated with the Pearl River, 
155 as well as rivers draining the Malay Peninsula, Sumatra, and to a lesser extent Western Borneo

156 (Liu et al., 2012). However, care should be taken when using clay minerals alone as provenance

157 proxies because they are also affected by environmental/climate conditions so that a particular

158 river will typically not have a stable clay mineral composition over long periods of geological

159 time (Hu et al., 2013). In addition, clay minerals may be subject to sorting by differential

160 flocculation during transport within a river mouth or the nearshore environments (Edzwald and

161 O'Melia, 1975; Gibbs, 1977).

162

\section{Analytical Methods}

One hundred bulk sediment samples were selected in order to provide an even

165 distribution through the entire age of the sequence at IODP Site U1433. Samples were first 166 decarbonated using $0.5 \%$ acetic acid. Decarbonation lasted for 3-4 days until no further fizzing

167 was observed with new acid. Samples were washed by deionized water before being ground into

168 powders. Approximately, 0.1 gram of sample was mixed with 0.4 gram of $\mathrm{LiBO}_{2}$ and heated in

169 an oven at $1500^{\circ} \mathrm{C}$. The melted samples were dissolved in $3 \%$ ultraclean $\mathrm{HNO}_{3}$, ultrasonicated,

170 dissolved, and diluted for analysis. The major element composition (Table 1) was determined by

171 Inductively Coupled Plasma Emission Spectrometry (ICP-ES) at Boston University, with

172 precision quantified to be better than $2 \%$ of the measured value for all elements. Accuracy was 173 constrained by analysis of certified Standard Reference Materials (BHVO-2), and results were

174 accurate within precision. Table S1 (online supplementary information) provides the results of

175 the repeated analyses of the standard and of the replicate analyses of Samples U1433B-60R-2,

$176 \quad 45-47 \mathrm{~cm}$ and 63R-1, 39-43 cm. 
Thirty two of the 100 decarbonated samples were also analyzed to determine ${ }^{143} \mathrm{Nd} /{ }^{144} \mathrm{Nd}$ 178 and ${ }^{86} \mathrm{Sr} /{ }^{87} \mathrm{Sr}$ values (Table 2). Prior to total digestion, all samples were leached again using 179 buffered acetic acid to remove any carbonate-bound Sr. Samples were digested using a standard $180 \mathrm{HF}-\mathrm{HNO}_{3}$ technique. For $\mathrm{Sr}$ and $\mathrm{Nd}$ separation samples were dissolved in 3:1 mixture of 181 concentrated $\mathrm{HF}$ and $\mathrm{HNO}_{3}$ on hot plate at $100^{\circ} \mathrm{C}$ for at least $24 \mathrm{hr}$, followed by three dry downs 182 in $6.2 \mathrm{~N} \mathrm{HCl}$. Prior to loading onto the ion exchange columns, samples were centrifuged to 183 remove any residual graphite. Solutions were loaded on to Sr-spec resin in order to separate $\mathrm{Sr}$ 184 isotopes, following the procedure outlined by Deniel and Pin (2001). One-step column chemistry 185 utilizing $\mathrm{Ln}$ resin was used for $\mathrm{Nd}$ separation. $\mathrm{Nd}$ and $\mathrm{Sr}$ isotopic compositions were determined 186 by Finnigan Neptune multi-collector inductively coupled plasma mass spectrometer (MC-ICP187 MS) at Woods Hole Oceanographic Institution. $\mathrm{Nd}$ and $\mathrm{Sr}$ isotope analyses were corrected 188 against La Jolla Nd standard ${ }^{143} \mathrm{Nd} /{ }^{144} \mathrm{Nd}=0.511847$ and NBS987 standard ${ }^{87} \mathrm{Sr} /{ }^{86} \mathrm{Sr}=0.710240$.

189 Procedural blanks for analyses were 20-25 pg for Sr (and 50-70 pg for Nd). The standard NBS 190987 was run to monitor machine performance and yielded an average ${ }^{87} \mathrm{Sr} /{ }^{86} \mathrm{Sr}$ of $0.710254 \pm 18$ 191 (27 ppm $2 \sigma, \mathrm{n}=24)$, which is within error of the multi-dynamic TIMS value of ${ }^{87} \mathrm{Sr} /{ }^{86} \mathrm{Sr}=$ $1920.710248 \pm 11$ reported by Thirlwall (1991). Nd isotope analyses were corrected against La Jolla $193 \mathrm{Nd}$ standard ${ }^{143} \mathrm{Nd} /{ }^{144} \mathrm{Nd}=0.511839 \pm 102 \sigma$. We calculate the parameter $\varepsilon_{\mathrm{Nd}}$ (DePaolo and 194 Wasserburg, 1976) using a ${ }^{143} \mathrm{Nd} /{ }^{144} \mathrm{Nd}$ value of 0.512638 for the Chondritic Uniform Reservoir 195 (CHUR (Hamilton et al., 1983)). Data is provided in Table 2. Because our samples are generally 196 fine grained and thus homogenous, especially after powdering, we did not anticipate that there 197 would be high errors in external reproducibility. Nonetheless, because very small proportions of 198 monazite/allanite control Nd isotopes (Garçon et al., 2014) samples were dissolved until no 199 residue was visible. To verify the magnitude of the external reproducibility we measured two of 
200 the samples three times each for $\mathrm{Nd}$ isotopes and twice for $\mathrm{Sr}$ in order to assess the uncertainty

201 (Table 2). We found that $\varepsilon_{\mathrm{Nd}}$ values only varied by 0.2 points between the repeats while ${ }^{87} \mathrm{Sr} /{ }^{86} \mathrm{Sr}$ 202 values differed by $\sim 0.00004$.

203 Clay mineralogy was determined by using X-Ray Powder Diffraction (XRD) at

204 Louisiana State University using a Panalytical Empyrean X-Ray Diffractometer. The same 100

205 samples were soaked in water until there was no flocculation, with $\mathrm{Na}_{3} \mathrm{PO}_{4}$ added to de-

206 flocculate when necessary. Four XRD patterns were generated from each oriented sample smear.

207 The first was collected from the sample in air-dried condition. The slide was then placed in a

208 desiccator with ethylene glycol for a minimum of eight hours at $25^{\circ} \mathrm{C}$, and the second XRD

209 pattern was generated from a glycolated sample. The third and fourth XRD data sets were

210 collected after the sample was subjected to heat treatments of $300^{\circ} \mathrm{C}$ for one hour, and then

$211550^{\circ} \mathrm{C}$ for one hour, respectively. XRD analysis began immediately after glycolation, and

212 immediately after the first heat treatment. In this study we use the semi-quantitative method of

213 Biscaye (1965) to estimate the clay assemblage, which is based on peak-intensity factors

214 determined from calculated XRD patterns as measured by MACDIFF software. For clay

215 minerals present in amounts $>10 \mathrm{wt} \%$ uncertainty is estimated as better than $\pm 5 \mathrm{wt} \%$ at the $95 \%$

216 confidence level. Uncertainty of peak area measurement based on repeated measurements is

217 typically $<5 \%$. We further calculate the illite chemistry index (the ratio of $5 \AA$ and $10 \AA$ peak

218 areas), and illite crystallinity (the full width at half maximum height of the illite $10 \AA$ peak)

219 determined on the glycolated curve. Illite chemistry indexes below 0.15 represent Fe-Mg-rich

220 illites (biotite, mica) characterized by physical erosion, whereas indexes above 0.4 are primarily

221 found in Al-rich illites (muscovite) formed by strong hydrolysis (Petschick et al., 1996). In

222 addition to calculating the relative concentrations of clay minerals in the samples, we also 
223 determine various ratios based on measurements of peak areas in the XRD patterns. These ratios

224 are used to reconstruct changes in relative abundance and are directly proportional to ratios

225 calculated from the exact values for individual mineral concentrations. Data are presented as

226 relative concentrations of the total clay assemblage in Table 3.

\section{$228 \quad 3 . \quad$ Results}

229 Selected results of the geochemical analysis are shown with the sedimentary log in Figure 2.

230 We use the widely applied chemical index of alteration (CIA; Nesbitt and Young (1982)) to

231 quantify weathering intensity. The CIA was developed for soils but is often applied to marine

232 sediments in order to assess the degree of chemical breakdown compared to fresh bedrock. This

233 proxy is calculated using the following formula, based on the notion that $\mathrm{Ca}, \mathrm{Na}$ and $\mathrm{K}$ are

234 depleted in most sediments as a result of chemical weathering, although recognizing that Na may

235 be more immobile in clays (Nesbitt et al., 1980):

$$
C I A=\frac{\mathrm{Al}_{2} \mathrm{O}_{3}}{\mathrm{Al}_{2} \mathrm{O}_{3}+\mathrm{CaO}^{*}+\mathrm{Na}_{2} \mathrm{O}+\mathrm{K}_{2} \mathrm{O}}
$$

236 where $\mathrm{CaO}^{*}$ is the calcium content from the silicate fraction of the sediment corrected for

237 phosphate contents (Singh et al., 2005). Because the sediments were decarbonated there is little

238 difference between CIA values derived using the phosphate correction or not and the trends are

239 similar. We slightly prefer the Singh et al. (2005) method as a way to insure against the

240 possibility of residual carbonate left after acid treatment. High CIA values are visible around 600

241 meters below seafloor (mbsf) and again around 350 mbsf (Fig. 2), above which level the values

242 tend to decrease towards the seafloor. The seafloor itself shows a relatively unweathered 
composition. Variations in the Chemical Index of Alteration of the sediment through time are shown in Figure 3. CIA values before 8 Ma show some cyclicity with higher and lower values on timescales of around 2 m.y. From 8 Ma to 6 Ma CIA is essentially constant, followed by a 2 m.y, long increase in CIA to $4 \mathrm{Ma}$, in turn followed by a progressive decrease to the present day. We also plot $\mathrm{Ni} / \mathrm{Zr}$ as a proxy for the involvement of Ni-rich mafic and ultramafic igneous rocks compared with zircon-bearing $\mathrm{Zr}$-rich granitic continental rocks. This ratio is high at $17 \mathrm{Ma}$ and then falls mostly progressively until $\sim 10 \mathrm{Ma}$. It remains largely constant through the past $8 \mathrm{Ma}$ (Fig. 3).

Both $\mathrm{Sr}$ and $\mathrm{Nd}$ isotopes show similar and consistent variability with depth. There is a zone below 700 mbsf with low values in ${ }^{87} \mathrm{Sr} /{ }^{86} \mathrm{Sr}(0.71-0.72)$, as well as less negative $\varepsilon_{\mathrm{Nd}}$ values (-5 to -8$)$. Above $700 \mathrm{mbsf}$ there is a change in both isotope systems with a long-scale decrease of ${ }^{87} \mathrm{Sr} /{ }^{86} \mathrm{Sr}$ values from $>0.73$ at $700 \mathrm{mbsf}$ to $\sim 0.723$ at the seafloor. $\varepsilon_{\mathrm{Nd}}$ seems to be slightly more consistent at a level of $\sim-11$ shallower than 700 mbsf. There is a brief departure to lower ${ }^{87} \mathrm{Sr} /{ }^{86} \mathrm{Sr}$ values and more positive $\varepsilon_{\mathrm{Nd}}$ visible between 400 and $500 \mathrm{mbsf}$ above which level the isotope ratios return to that seen below 500 mbsf.

particularly abundant below $\sim 680$ mbsf, above which level it falls in a consistent fashion towards around 160 mbsf, being more constant at shallower depths. Chlorite and kaolinite are relatively scarce in the sequence, especially towards the bottom where they form a small fraction of the total clay assemblage. They rise in abundance above $680 \mathrm{mbsf}$ but remain less than $20 \%$ of the total assemblage. Illite is the second most abundant clay mineral in the sediments and shows a reverse trend to that seen in the smectite, being low at the base of the sequence and rising steadily up-section, reaching a level of around $40 \%$ close to the seafloor. Because the total clay 

284 case.

assemblage is normalized to $100 \%$ the increase in illite up-section may simply reflect less smectite. Many of the clay mineral abundances appear to be less variable in the upper $250 \mathrm{~m}$ of the section, although sampling density was less because of the higher sedimentation rate.

\section{Discussion}

\subsection{Chemical Weathering Proxies}

While changes in CIA measured alteration intensity and may be linked to climate change causing changes in weathering rates grain size variations may also control this proxy, reflecting the fact that some of the sediments are silty turbidites, coarser than the dominant muds. We use $\mathrm{Si} / \mathrm{Al}$ as a proxy for the grainsize of the sediment because quartz sand has higher $\mathrm{Si} / \mathrm{Al}$ values than silt which is turn has higher values than clays (Lupker et al., 2011). Temporal variations in $\mathrm{Si} / \mathrm{Al}$, and in $\mathrm{Si}$ alone, are similar to those in CIA (Fig. 4), suggesting that there is close link between quartz sand content and degree of alteration. This is not a direct consequence of the presence of quartz but rather the loss of unstable minerals. For example, the silt fraction may contain abundant micas that have lower CIA values than clays (Andrews et al., 2013). Quartzrich sediment tends to be less altered than clay-rich material, which is consistent with earlier studies (Hoang et al., 2009) and the idea that clay is itself an alteration product. Consequently we do not consider CIA to be a good tracer of environmental conditions in the source regions in this

Clay mineral assemblages may also be used to interpret paleo-weathering conditions, because these are unaffected by other coarser mineral species. Clays have been used to examine changes in weathering assuming that clay mineral formation is a direct response to 
environmental conditions (Thiry, 2000). Soil forms rapidly and to greater depths in tropical and subtropical environments, where chemical weathering is intensified by the process of leaching (Birkeland, 1984). As a result, kaolin-group minerals are frequently abundant in well-developed (meters thick) soils from regions of tropical climate with high rainfall, whereas warm regions with more seasonality and thus with less leaching, are more prone to producing smectite-rich soil (Hillier, 1995).

Clay mineral records from the South China Sea show a good correspondence between clay assemblages and the intensity of the East Asian monsoon over periods $>10^{6} \mathrm{yr}$ (Wan et al., 2007). Recently, it has also been suggested that changes in mineralogy linked to millennial-scale variations are recorded in sediments from other Asian continental margins (Boulay et al., 2007; Colin et al., 2010; Liu et al., 2010; Liu et al., 2005), implying that the clay minerals in a weathering system can respond and leave a record even on time scales much shorter than those considered here.

Temporal evolution in smectite/(illite + chlorite) and kaolinite/(illite + chlorite) is shown in Figure 3. Prior to $8 \mathrm{Ma}$ there is significant variation in the record, with particularly high relative abundances of smectite seen around 9,12 and 15.5 Ma. Several of the changes in the relative abundance of smectite correlate with times of change in the Nd- and Sr isotopes, suggestive of a provenance control, as discussed below. 
The progressive evolution in $\mathrm{Ni} / \mathrm{Zr}$ suggests stronger erosion from Ni-bearing rocks prior to $12 \mathrm{Ma}$ and lesser involvement from typical granitic zircon rich sources. Ni is most common

311 ultramafic and mafic igneous rocks. Mielke (1979) reported values for Ni in igneous rocks as:

312 ultramafic $2000 \mathrm{mg} \mathrm{kg}-1$, basaltic $130 \mathrm{mg} \mathrm{kg}-1$ and granitic $4.5-15 \mathrm{mg} \mathrm{kg}-1$. This is supportive

313 of some mafic igneous, possibly ophiolitic source in the early stages of the basin sedimentation.

314 We explore this further with simple trace element discrimination diagrams. Figure 5A, from

315 Hiscott (1984) shows that a typical ophiolitic source including peridotites and other deep crustal

316 ultramafic would be expected to have high $\mathrm{Cr} / \mathrm{V}$ and low $\mathrm{Y} / \mathrm{Ni}$ values. The sediments from Site

317 U1433 scatter between the Post-Archean Australian Shale (PAAS, a proxy for fine grained

318 sediment derived by erosion of the upper crust) and Upper Continental Crust averages of Taylor

319 and McLennan(1985). The samples show little indication of strong ophiolitic involvement and

320 are in many respect typical of erosion from continental sources.

321 Use of the $\mathrm{TiO}_{2}$ versus $\mathrm{Zr}$ plot of Nagarajan et al. (2014), designed for analysis of

322 sediments in Borneo further reinforces this provenance interpretation (Fig. 5B). With a small

323 number of extreme exceptions the sediments plot on the boundary between the felsic and

324 intermediate rock fields, consistent with a general continental source and ruling out a dominant

325 flux from mafic igneous sources around the South China Sea, such as Luzon, Palawan or the

326 Vietnamese Central Highlands. 
331 sharp change close to $8 \mathrm{Ma}$, with lower $\varepsilon_{\mathrm{Nd}}$ values and higher ${ }^{87} \mathrm{Sr} /{ }^{86} \mathrm{Sr}$ values dominating after

332 that time. The change is especially striking in terms of ${ }^{87} \mathrm{Sr} /{ }^{86} \mathrm{Sr}$. Before $8 \mathrm{Ma}$ there is significant

333 variability, with phases of greater stability in isotope character separated by times of rapid

334 change.

Recent work shows that the $\mathrm{Nd}$ content of sediment is largely controlled by the presence

336 of monazite and allanite, which are not separated by mineral sorting and the $\mathrm{Nd}$-isotopic signal is

337 thus relatively insensitive to hydrodynamic sorting during transport (Garçon et al., 2013; Garçon

338 et al., 2014). Moreover, because the Nd- and Sr-isotopic signals are similar this suggests that the

339 Sr signal is not significantly affected by chemical weathering or by mineral sorting during

340 transport in this particular case, as marked by the strong inverse correlation shown in Figure 6

341 (correlation coefficient R2=0.77).

We can better constrain provenance by comparing sedimentary values with those known

343 from potential source areas. The sediment at Site U1433 is close to the modern Mekong River in

$344 \varepsilon_{\mathrm{Nd}}$ values after $8 \mathrm{Ma}$ (Fig. 6), although the ${ }^{87} \mathrm{Sr} /{ }^{86} \mathrm{Sr}$ values are higher than the modern river

345 sediments during this time period. This may imply input from the Mekong River system to the

346 deep South China Sea. $\varepsilon_{\mathrm{Nd}}$ values change from being more positive than the modern Mekong in

347 sediments older than 9 Ma to being more negative, or within the range of modern river sediments,

348 in those younger than 8 Ma. Before 9 Ma source variation was significant and seems to correlate

349 with CIA and some clay mineral ratios (Fig. 3). Relatively positive $\varepsilon_{\mathrm{Nd}}$ values before 9 Ma are

350 indicative of sediment input from very different sources than those that have dominated the area

351 since $8 \mathrm{Ma}$. The positive $\varepsilon_{\mathrm{Nd}}$ values require input from relatively juvenile sources rather than

352 older continental crust, which is more important in the younger part of the record. 
A number of possible sources could account for the range of sediment isotope compositions in the deep SW basin, although some are better characterized than others. In

355 Borneo there is no isotopic information concerning possible bedrock sources from the onshore

356 itself, so we are forced to infer possible source compositions from the modern shelf sediment,

357 although this is poorly defined on the basis of a small number of samples around its coast (Wei et

358 al., 2012). Borneo is unlikely to be a major supplier of sediment to Site U1433 because of the

359 bathymetric barriers that separate it from the deep South China Sea, favoring most sediment

360 being preserved closer to source. Seasonal currents also tend to move suspended sediment to the

361 NE and SE and not towards Site U1433. Similarly, the Red River is not a practical source of

362 sediment to Site U1433 because it lies too far to the north and sediment from this river is

363 captured in the Song Hong-Yinggehai Basin, as well as the Xisha Trough in the northern South

364 China Sea. Modern Taiwanese river sediments span a range of $\mathrm{Sr}$ and $\mathrm{Nd}$ isotope values that are

365 similar to the Site U1433 sediments but generally plot with lower ${ }^{87} \mathrm{Sr} /{ }^{86} \mathrm{Sr}$ values. The great

366 distance between the site and Taiwan, as well as the opposing summer surface currents tend to

367 argue against this is being a major supplier to the area.

368 Small coastal rivers draining Indochina also have high ${ }^{87} \mathrm{Sr} /{ }^{86} \mathrm{Sr}$ values and relatively 369 negative $\varepsilon_{\mathrm{Nd}}$ values. A study of the Song Gianh, which drains the coastal Annamite Range at $370 \sim 18^{\circ} \mathrm{N}$ (Jonell et al., 2016), shows the potential of such rivers to act as suppliers of clastic 371 sediment to the drill site. The Song Gianh itself is located too far north to have been a significant 372 source, but similar rivers located further south, and also eroding Indochina basement, might 373 provide isotopically similar material to the drill site where they could mix with sediment from 374 other sources. Such transport would be favored by the narrow continental shelf located offshore 
southern Vietnam. Possible influence of such Annamite sources is strongest in the younger samples (<8 Ma) with ${ }^{87} \mathrm{Sr} /{ }^{86} \mathrm{Sr}$ values higher than those known in the modern Mekong.

The modern Mekong River is a likely dominant source of sediment to the site in more recent geological times given its proximity to the shelf edge of the SW basin and the clear sediment transport pathway. The known isotopic range of sediments in the modern Mekong is relatively restricted, but has lower ${ }^{87} \mathrm{Sr} /{ }^{86} \mathrm{Sr}$ values and slightly higher $\varepsilon_{\mathrm{Nd}}$ values compared to many of the analyses that postdate $8 \mathrm{Ma}$. This means that the sediment at Site U1433 cannot be exclusively derived from the Mekong. The past composition of the Mekong River is, however, presently unconstrained and this requires us to use the modern river as an approximate estimate for the long-term input. The Mekong itself likely changed composition in the past, possibly because of changing drainage basin geometry and chemical weathering/environmental conditions. The post-8 Ma samples fall between the range of the Mekong River and Annamite Range rivers, indicating that a mixture between these sources could account for the measured ratios. Input from other sources is possible but likely to be small after $8 \mathrm{Ma}$.

The influence of the Pearl River can also be considered although sediment from the river now largely moves to the west of its delta towards Hainan (Liu et al., 2009a) and the river is both far from the drill site and separated from it by the relict oceanic ridge. The Pearl River is presently highly anthropogenically impacted so that its modern samples are elevated in ${ }^{87} \mathrm{Sr} /{ }^{86} \mathrm{Sr}$ compared to the natural state. We use the range of Holocene analyses from the Pearl River mouth from Hu et al.(2013) rather than the modern samples of Liu et al.(2007) because that study eliminated the anthropogenic effect and more importantly capture the composition of the river entering the South China Sea rather than identifying end member tributaries in the headwaters whose extreme compositions were likely never delivered to the delta in an undiluted 
form. The Pearl River delta plots around the Mekong samples, making it impossible to resolve

399 the two based on this method alone. Although Liu et al. (2007) suggested that the modern rivers

400 could be distinguished on the basis of $\mathrm{Sr}$ and $\mathrm{Nd}$ isotopes consideration of the entire Holocene

401 compositional range of the Pearl River now demonstrates that this is not possible (Hu et al.,

402 2013).

Samples older than $8 \mathrm{Ma}$ are more complex to interpret and are more variable. These

404 show lower ${ }^{87} \mathrm{Sr} /{ }^{86} \mathrm{Sr}$ values and less negative $\varepsilon_{\mathrm{Nd}}$ values than the Mekong, and could represent

405 mixture from a number of sources, including the Annamite Range (Indochina), Borneo, and

406 possibly a paleo-Mekong, as well as more primitive volcanic sources. The highest $\varepsilon_{\mathrm{Nd}}$ value seen

407 in the 12-18 Ma sediments cannot be explained by mixing of Indochina-derived sediment and

408 Borneo-derived sediment (Fig. 6). This implies some sediment delivery from an even more

409 primitive source. In any case, significant erosion from Borneo prior to 12 Ma seems unlikely,

410 because although collision between Dangerous Grounds and Borneo 16 Ma was driving uplift,

411 this started first in the south of that island, with the North only uplifting in the Late Miocene

412 (Honza et al., 2000; Hutchison, 2005).

The basement of the Dangerous Grounds themselves has been locally dredged and found

414 to be igneous (diorite and olivine gabbro) (Hutchison and Vijayan, 2010). The Dangerous

415 Grounds are now submerged and have likely been submarine through the time of sedimentation

416 at Site U1433, coinciding with the collision between Borneo and Dangerous Grounds (Clift et al.,

417 2008; Hutchison, 2005). Consequently it is unlikely that this block could have been a significant

418 source of sediment to Site U1433. 

appears to have experienced most of its uplift during the Plio-Pleistocene and was probably not

421 being heavily eroded before $8 \mathrm{Ma}$ (Shi et al., 2011). Possible volcanic sources exist in the

422 seamounts of the South China Sea itself (likely with low ${ }^{87} \mathrm{Sr} /{ }^{86} \mathrm{Sr}$ and high $\varepsilon_{\mathrm{Nd}}$ values) and the

423 drill site is located close to some prominent features that were emplaced along the old seafloor

424 spreading axis. Other possible primitive sources could include the volcanic rocks of the Central

425 Highlands of Vietnam. However, these largely erupted after $8 \mathrm{Ma}$, when this area was rapidly

426 uplifted and dissected (Carter et al., 2000), and therefore these sources cannot explain the isotope 427 excursions seen in the pre-8 Ma record.

Thus a number of possible sources could contribute to the pre- 8 Ma sediments. The

429 Luzon Arc is a possible contributor but large volumes of flux are unlikely because it was distant

430 ( 950 km today, cf., $730 \mathrm{~km}$ from the Mekong Mouth) and located to the SE of the present

431 location at that time as a result of the ongoing subduction under the Philippine (Hall, 2002).

432 Summer surface currents in the modern South China Sea are dominantly flowing to the NE (Chu 433 and $\mathrm{Li}, 2000$ ), which also argues against significant fine grained sediment transport from Luzon.

434 Transport by bottom or turbidity currents from Luzon is less likely because of the existence of 435 major bathymetric barriers such as the Manila Trench. Nonetheless, mixing with an end member 436 within the Luzon isotopic range could explain some of the isotopic variability seen in the 437 samples older than 8 Ma (Fig. 6). 
442 Weber, 1919) during recent glacial low stands it is unlikely that this would have been possible 443 prior to $8 \mathrm{Ma}$ when sea level was significantly higher (Haq et al., 1987).

We favor modest input from Palawan as a possible source of sediment with low ${ }^{87} \mathrm{Sr} /{ }^{86} \mathrm{Sr}$ and positive $\varepsilon_{\mathrm{Nd}}$ values. Although there is limited isotopic data from this island (one sample from 446 Fang et al. (1992)), Palawan island exposes ophiolite rocks with suitable isotopic values that 447 could account for some of the range seen at Site U1433. This ophiolite was emplaced on to 448 continental crust in the Oligocene to Early Miocene (Aurelio et al., 2013; Savva et al., 2014) and 449 would have been available for erosion at the time of sedimentation. Although southern Palawan 450 is partly separated from the deep basin by the Sabah Trough, the northern parts of the island 451 would have had a direct transport pathway ( 500 km long) downslope towards Site U1433 after 452 the collision between Dangerous Grounds and Borneo-Palawan. Flux from Palawan cannot have 453 been too strong from the ultramafic base of the ophiolite, when we consider the low $\mathrm{Cr} / \mathrm{V}$ values 454 of the sediment (Fig. 5A).

We try to estimate the possible role of primitive volcanic rocks by constructing mixing

456 lines between an Indochina end member and both Palawan and Luzon Arc end members (Fig. 6), 457 since together these can account for the range of variability seen in the sediments. Mixing only 458 between Indochina and Palawan can explain some of the variability, but many of the sediments 459 plot above the mixing line, indicating that at least one more source is needed to explain all the 460 variability, possibly Luzon. Sedimentation rates prior to $8 \mathrm{Ma}$ were generally low and it is 461 possible that the positive $\varepsilon_{\mathrm{Nd}}$ sediment represents material from several primitive sources. Using 462 the isotope proxies alone it is not possible to resolve between these alternatives (i.e., Palawan, 463 Luzon, intra-basin seamounts or volcanic rocks in Borneo). 


\subsubsection{Clay Minerals and Provenance}

Clay minerals can also be an aid to provenance because they are partly linked to source as well as environmental conditions. Because climatic variations are known to generate major changes in clay mineralogy, comparable to source rocks compositional differences (Hu et al.,

4692013 ) any provenance interpretation based on clays must be compared with other data sets to be considered robust. The effectiveness of clay mineral ratios as provenance proxies can be

471 investigated by comparing clay ratios with $\varepsilon_{\mathrm{Nd}}$ values. Figure 8A shows the relationship between

472 kaolinite/smectite and $\varepsilon_{\mathrm{Nd}}$ values. There is a basic correlation between the isotope composition

473 and kaolinite/smectite. This implies that sediment with the most negative $\varepsilon_{\mathrm{Nd}}$ values tends to 474 have the highest kaolinite/smectite values. This is consistent with the idea that smectite is largely 475 eroded from juvenile volcanic sources, so that abundances of smectite are low when $\varepsilon_{\mathrm{Nd}}$ values 476 are more negative. The correlation indicates that this clay mineral ratio is largely provenance 477 driven. Likewise, we can examine the provenance dependence of smectite/(illite+chlorite) in 478 Figure $8 \mathrm{~B}$. The relationship is less clear in this case, but it is also apparent that the highest values 479 in the clay mineral ratio are only found with the most positive isotopic values, showing some 480 provenance control. Figure $8 \mathrm{C}$ shows a good overall correlation between $\varepsilon_{\mathrm{Nd}}$ values and 481 kaolinite/(illite+chlorite) again indicative of a dominant provenance control on the clay ratio.

483 and because we know that there is a significant provenance change prior to $\sim 8 \mathrm{Ma}$ we propose 484 that reduced smectite abundance at that time is probably linked to the reduction in relative input 485 of juvenile volcanic-derived sediment. We use a triangular plot to assess the relative contribution 
of chemically weathered kaolinite and smectite compared with physically eroded illite and chlorite. Figure 9 shows that there is a wide range of compositions at the drilling site, but that sediments older than $8 \mathrm{Ma}$ are consistently richer in smectite, while younger sediments trend towards illite and chlorite. Younger sediments tend to plot close to known compositions from the modern Red and Mekong, as well as Taiwan, whereas the older ( $>8 \mathrm{Ma}$ ) sediments approach the composition of sediments sampled offshore Luzon and in rivers draining northern Palawan (Liu et al., 2016). Although some samples younger than 8 Ma overlap the Holocene composition of the Pearl River delta many plot with higher illite + chlorite contents and the trend appears to extend towards an end member similar to the Red River but close also to the modern Mekong, for which no pre-modern samples have yet been measured. The modern Mekong River field is likely displaced towards higher kaolinite contents compared to its older composition as a result of agriculture in the basin, as noted in the Pearl River (Hu et al., 2013).

The clay mineral data argue strongly against significant sediment delivery from arc sources in Sumatra or the Malay Peninsula, or from volcanic sources in Borneo. However, the progressive development of a more physically eroded illite and chlorite-rich assemblage is consistent with a shift in provenance from juvenile volcanic sources to more continental 502 influence.

We further explore the potential use of clay minerals to determine sediment provenance 504 by consideration of the illite chemistry index (Petschick et al., 1996), together with the ratio 505 kaolinite/(illite+chlorite), following the study of Hu et al. (2014). Figure 10 shows that the sediments at Site U1433 comprise a relatively restricted range, largely lying within the physical

507 weathering regime, with moderate degrees of hydrolysis due to chemical weathering. They are 508 
Mekong Rivers but contrast with strongly chemically weathered sediments Hainan Island, as

510 well as the Pearl River. Such a pattern is consistent with our earlier provenance conclusions

511 emphasizing flux from Indochina after $8 \mathrm{Ma}$ and ruling out significant sources in southern China

512 or Hainan. Modern rivers in the Malay Peninsular and Sumatra have kaolinite/(illite+chlorite)

513 values $>3.5$ and are clearly excluded (Liu et al., 2012).

The highest illite chemical index values appear to be associated with sediments older than

$5158 \mathrm{Ma}$, and there is relative stability in illite chemistry and illite crystallinity indices in sediments

516 younger than $8 \mathrm{Ma}$. Sediment appears to be largely derived from areas experiencing strong

517 physical erosion and would be consistent with much of the sediment coming from the Mekong

518 and associated rivers draining Indochina since $8 \mathrm{Ma}$. The Mekong derives most of its sediment

519 load from its headwaters in SE Tibet (Clift et al., 2006b). The Pearl River is not a good match

520 based on these proxies. The clay mineral compositions argue against major derivation of

521 sediment from southern Borneo at any time since $17 \mathrm{Ma}$.

\subsection{Mekong River Flux to South China Sea}

We argue that most of the sediments at Site U1433 have been derived from the Mekong

525 River since $8 \mathrm{Ma}$, with lesser input from other small rivers in Vietnam. Between 8 and $4 \mathrm{Ma}$

526 there is slightly more Sr isotopic difference between the sediments and the modern Mekong

527 River compared to after $4 \mathrm{Ma}$, and this may reflect either a change in the average composition of

528 that river since that time, or possibly additional flux from more continental sources directly from

529 the coast of Indochina. Nonetheless, the change at $4 \mathrm{Ma}$ is modest, compared to that at $8 \mathrm{Ma}$.

530 Relative isotopic stability since $8 \mathrm{Ma}$ argues that the Mekong River has been the primary 
531 sediment source after that time and that therefore the river mouth has been in its present location

532 since then. This is older than other seismically derived estimates from the region, which have

533 mostly placed the time of initiation of the Mekong in the present position at around $5 \mathrm{Ma}$ or

534 younger (Li et al., 2013; Murray and Dorobek, 2004). Our data are compatible with this earlier

535 interpretation because our distal location means that Site U1433 might be receiving muddy

536 sediment in plumes from the river mouth at an early stage after the establishment of the mouth in

537 its present location but before the delta clinoforms had migrated into the shelf edge areas covered

538 by the seismic surveys. Regional sediment budgets for this area (Ding et al., 2016) show a sharp

539 increase in sedimentation rates at around this time, consistent with the Mekong either initiating

540 or moving its mouth to the present location around this time. Although the age of the Mekong in

541 the SW South China Sea is much younger than many of the other large rivers in SE Asia (Clift et

542 al., 2006a; Robinson et al., 2013; Zheng et al., 2013) our data does not preclude the existence of

543 an older Mekong River, probably in the Gulf of Thailand, but would only argue for it moving its

544 mouth to the present location in the Late Miocene.

545 Although there is evidence for accelerated uplift in SE Tibet-SW China, in the

546 headwaters of the Mekong after 9-13 Ma (Clark et al., 2005) uplift in that area began much

547 earlier (Wang et al., 2012), so that it seems unlikely that the plateau uplift triggered the move of

548 the Mekong mouth to the present location at around $8 \mathrm{Ma}$. The fact that the Yangtze, Irrawaddy

549 and Red Rivers have much older histories, but are also sourced from eastern Tibet, further

550 supports the idea that accelerated Late Miocene uplift did not cause the Mekong River to initiate

551 and implies that the change we observe is linked to avulsion of the lower reaches.

It is not apparent why the Mekong River would move its mouth from an earlier location 
course. It is possible that this is linked to the uplift of the Central Highlands of Vietnam at around this time (Carter et al., 2000). However, it is noteworthy that the Gulf of Thailand itself shows reduced sedimentation after this time (Clift, 2006) when sediment input to the SW South China Sea increased (Ding et al., 2016). It is possible that the basins in the Gulf of Thailand had been largely filled at that point and that the lack of accommodation space caused the river mouth to avulse towards the southeast from its earlier location.

The geochemical and mineralogical history we reconstruct at Site U1433 is markedly different from that recorded on the northern margin of South China Sea adjacent to mainland China. Since both areas share a similar monsoonal climate we would argue that these differences are largely related to changes in sediment provenance. Figure 11 compares records of kaolinite/illite from IODP Site U1433, as well as from ODP Site 1146 on the northern margin and ODP Site 1143 in the Dangerous Grounds, whose clastic sediment has been inferred to come from the Mekong (Wan et al., 2006). Kaolinite/illite is typically linked to the degree of chemical weathering, yet there is no correlation between the record on the northern margin and at Site U1433. The northern margin data show a general decrease in chemical weathering intensity from $8 \mathrm{Ma}$ to the present day, correlating with the increasingly cold conditions related to global environmental degradation over that same time (Clift et al., 2014). In contrast, kaolinite/illite at Site U1433 shows a cyclicity through time, closely mirroring the record at ODP Site 1143 (Fig. 11). We argue that this correlation with ODP Site 1143, but not with the northern margin, represents a change in the sediment provenance linked to the Mekong River in the SW basin. Indeed the fact that kaolinite/illite values at ODP Site 1143 and IODP Site U1433 not only track each other but are of the same value indicates that they share a common source, i.e., the Mekong. Unfortunately clay mineral analysis of sediment at ODP Site 1143 has not addressed sediment 
577 older than 8.5 Ma, which allows us only to compare the records after the onset of Mekong

578 sediment delivery to the SW South China Sea.

\section{Conclusions}

We applied a series of geochemical and mineral proxies to the study of sediment from IODP Site U1433 in the SW South China Sea. The objective of our study was to use sedimentary records to reconstruct evolving tectonic and erosional conditions since around $17 \mathrm{Ma}$. We exploited the tectonic diversity in Southeast Asia, which allows us to resolve sediment eroded

585 from different sources blocks using a matrix of different proxies. Our results show significant temporal variation in the composition of sediment reaching the drilling site with a particularly

587 large change at $\sim 8 \mathrm{Ma}$. Prior to $8 \mathrm{Ma}$ we see substantial variation in the intensity of chemical 588 alteration, as well as in $\mathrm{Sr}$ and $\mathrm{Nd}$ isotope characteristics that suggest significant variability of

589 sediment sources at 8-17 Ma. In sediments younger than $8 \mathrm{Ma}$ there is greater stability, with 590 compositions lying relatively close to that of the modern Mekong River. Attempts to use proxies 591 such as the CIA or clay minerals to examine the evolving state of chemical weathering proved to

592 be unsuccessful because the degree of alteration is largely controlled by the provenance and 593 quartz content of the sediment.

The source of sediment can be best constrained by looking at the $\mathrm{Sr}$ and $\mathrm{Nd}$ isotope 595 characteristics of the clastic fraction. This shows that sediments predating $8 \mathrm{Ma}$ tend to be 596 eroding from more primitive, juvenile crust, but still dominated by a flux of sediment from 597 mainland Indochina. A number of possible volcanic sources were identified, although we favor 598 erosion from Palawan where the ophiolite was already exposed prior to $17 \mathrm{Ma}$ and where the 
sediment transport path downslope is clear. Elevated $\mathrm{Ni} / \mathrm{Zr}$ values before $10 \mathrm{Ma}$ also argue for

600 some flux from a source of this variety. We do not exclude some additional flux from the Luzon

601 arc, although paleogeography and modern current activity suggest that this is not significant.

602 Borneo was located too far to the south to be a significant source before $8 \mathrm{Ma}$ and the known

603 clay mineral assemblage is also inconsistent.

Clay mineral assemblages show that the sediment older than $8 \mathrm{Ma}$ is substantially

605 dominated by smectite, again reflecting the more volcanic juvenile sources of that earlier time.

606 After that time we see an evolution towards clays that are more dominated by illite and chlorite,

607 indicative of stronger physical erosion. Sediments younger than $8 \mathrm{Ma}$ have compositions close to

608 those of the modern Mekong River, which is presumed to dominate the sediment supply. Just as

609 the geochemistry was largely controlled by quartz content (and provenance) so also the clay

610 mineral composition appears to be largely a function of these factors rather than reflecting

611 environmental conditions at the time of sedimentation.

Our records show significant differences in the geochemical and mineral history between

613 SW South China Sea and the northern margin. We learn little about long-term variation in

614 monsoon intensity from this record, but the significant change in provenance especially around 8

615 Ma is indicative of a start to the Mekong River in its present location. Modern differences

616 between the Mekong and sediments deposited between 8 and 5 Ma thus may reflect either

617 evolution in the Mekong River itself, or more likely additional input from other smaller rivers

618 draining coastal Indochina at that time. An 8 Ma initiation of the Mekong River in the present

619 location is consistent with seismic data but does not require the river to be that young, only to

620 have experienced avulsion of its mouth out of the Gulf of Thailand at that time. 
622 Acknowledgments

623 This research used samples and/or data provided by the International Ocean Discovery Program

624 (IODP). Funding for this research was provided by U.S. Science Support Program and the

625 Charles T. McCord chair in petroleum geology at Louisiana State University. Portions of this

626 material are based upon work supported while RWM was serving at the National Science

627 Foundation. The manuscript has been improved thanks to comments from two anonymous

628 reviewers.

629 
632 Figure 1. Bathymetric map of the South China Sea indicates the location of IODP Site U1433

633 that is the subject of this study. Topography is from Shuttle Radar Topography Mission (SRTM)

634 plotted by GeoMapApp. Major fluvial systems which deliver sediments into the South China Sea

635 are also shown, together with the Molengraaff River of glacial age crossing the Sunda Shelf

636 (Molengraaff and Weber, 1919). Yellow arrows show surface currents active during summer

637 monsoon (Fang et al., 1998). Isobaths are shown in $1000 \mathrm{~m}$ intervals. Vietnamese Central

638 Highlands $=$ VCH. SG $=$ Song Gianh.

Figure 2. Geochemical variations at IODP Site U1433 plotted against depth. There is a trend towards lower CIA above $\sim 250 \mathrm{msbf}$ above the zone of frequent calcareous turbidites. Note that both $\mathrm{Nd}$ and $\mathrm{Sr}$ isotopes show a two stage trend with a break at $700 \mathrm{mbsf}$. Uncertainties for Nd are the external reproducibility. Those in Sr isotopes are within the size of the plotted symbol. LSR = linear sedimentation rate. Uncertainties in Sr isotope composition are within the size of the plotted symbols. Sedimentation rates are calculated from shipboard magnetic and biostratigraphic constraints (Li et al., 2015), with no sediment compaction correction.

Figure 3. Geochemical and mineralogical proxies for weathering intensity and provenance at IODP Site U1433. Sediment flux for the Mekong delta derived from regional seismic data is from Clift (2006). Uncertainties in the isotope ratios are smaller than the symbols plotted. Horizontal gray bars show periods of anomalous high $\varepsilon_{\mathrm{Nd}}$ values, suggestive of a different provenance. DRU = Deep Regional Unconformity of Hutchison (2005). "Seismic delta" represents the time of the oldest foresets of the Mekong delta identified by Li et al. (2013).

654 Uncertainties in Sr isotope composition are within the size of the plotted symbols. CIA and 655 kaolinite/(illite+chlorite) are shown with raw data in gray and a 5-point running average in black 656 drawn to emphasize the long term changes. Sealevel curve is from Haq et al. (1987). proxies suggestive of a major quartz silt-sand control on chemical weathering intensity. Five

661 point running average is used to show the long wavelength variation which makes the parallel 662 evolution easier to appreciate. 
664 Figure 5. Trace element discrimination diagrams to determine tectonic setting. (A) $\mathrm{Cr} / \mathrm{V}$ versus 665 Y/Ni from Hiscott (1984). PAAS = post-Archean Australian shale, UCC = Upper Continental 666 Crust (Taylor and McLennan, 1985), and (B) $\mathrm{TiO}_{2}$ versus $\mathrm{Zr}$ concentrations from Nagarajan et al. 667 (2014).

668 Figure 6. Plot of Sr versus Nd isotopes for the samples from IODP Site U1433 broken into four

669

670

671

672

673

674

675

676

677

678

679

680

681

682

683

684

685

686

687

688

689

690

691

692

693

694

695

696

697

698

699 separate age populations and compared with potential source bedrock compositions and other known sediment compositions from the region. Annamite Range river is from Jonell et al. (2016), Red and Mekong River is from Liu et al. (2007), offshore Borneo, Dangerous Grounds sediment data are from Wei et al. (2012), Palawan is from Tu et al. (1992), Sumatra data is from White and Patchett (1984). Luzon data is from Knittel et al. (1988). Hainan bedrock data is from Fang et al. (1992). Taiwan River data is from Chen and Lee (1990) and Lan et al. (2002). Pearl River data is from $\mathrm{Hu}$ et al. (2013). Stars show mixing end members with the curves showing possible compositions between these sources. Indochina end member has $\mathrm{Sr}$ and $\mathrm{Nd}$ concentrations of 120 and 40.1 ppm respectively from Liu et al. (2007) measurements of the Red and Mekong Rivers. The Palawan end member has Sr and Nd concentrations of 542 and 19 ppm from Tu et al. (1992). The Luzon arc end member has $\mathrm{Sr}$ and $\mathrm{Nd}$ concentrations of 439 and 19.1 ppm respectively, averaged Luzon data from Georoc.

Figure 7. Paleogeographic map of the South China Sea at $8 \mathrm{Ma}$ and $17 \mathrm{Ma}$. Luzon and the Philippine arc have been moving from the Pacific towards the South China Sea progressively over this interval. Note emergence of Borneo prior to $8 \mathrm{Ma}$ and the emplacement of the Central Highlands (CH) lavas at 8 Ma. Map modified from Hall (2002).

Figure 8. Plots of $\varepsilon_{\mathrm{Nd}}$ values and select clay mineral ratios show some correlation between provenance and clay mineral assemblage. (A) Smectite/kaolinite versus $\varepsilon_{\mathrm{Nd}}$ values indicates more smectite in sediments with more primitive provenance (higher $\varepsilon_{\mathrm{Nd}}$ values). (B)

Smectite/(chlorite+illite) shows higher values from samples older than $8 \mathrm{Ma}$, together with more positive $\varepsilon_{\mathrm{Nd}}$ values. (C) kaolinite/(illite+chlorite) shows a good overall correlation, but a poor within the 0-4 Ma group.

Figure 9. Ternary diagram of clay minerals from IODP Site U1433 indicates shift in clay mineral assemblage from smectite-dominated to illite and chlorite dominated with younger ages, as shown in Figure 3. Clay mineral data from other fluvial systems are plotted to compare their clay mineral assemblages. Red and Mekong River data are from Liu et al. (2007). Pearl River data are from $\mathrm{Hu}$ et al. (2013). Taiwan data is from Liu et al. (2010). West Borneo, Malay Peninsula, Sumatra, Luzon data are from Liu et al. (2012). Palawan data is from Liu et al. (2016a). 
701 Figure 10. Correlation of kaolinite/(illite + chlorite) with illite chemical index, showing the

702 different forcing processes on the clay mineral assemblages in the surrounding areas. Figure and

703 Hainan river data are modified from $\mathrm{Hu}$ et al. (2014). Pearl, Mekong and Red River points

704 represent averages from Liu et al. (2007). Average Taiwan river data are from Liu et al. (2008).

705 Average Borneo river data are from Liu et al. (2012)

706

707 Figure 11. Temporal evolution in kaolinite/illite at Site IODP U1433 compared to similar data 708 from the northern margin of South China Sea at ODP Site 1146 (Wan et al., 2007) and in the SW, 709 Dangerous Grounds at ODP Site 1143 (Wan et al., 2006). Chemical weathering is compared with 710 global compilation of the Zachos et al. (2001).

711

712 Table 1. Major element composition of sediments derived by ICP-ES.

713

714 Table 2. Strontium and neodymium isotope compositions. External precision of the ${ }^{87} \mathrm{Sr} /{ }^{86} \mathrm{Sr}$ and

$715{ }^{143} \mathrm{Nd} /{ }^{144} \mathrm{Nd}$ measurements is estimated to be $0.000015-0.000025(2 \sigma)$ and $0.000010-0.000020$

$716(2 \sigma)$ respectively.

717

718 Table 3. Calculated clay mineral assemblages derived from XRD analysis.

719

720 Table S1. Major and trace element composition of replicate analyses and standards. 


\section{References}

Andrews, J.E., Brimblecombe, P., Jickells, T.D., Liss, P.S., Reid, B., 2013. An Introduction to Environmental Chemistry. John Wiley \& Sons, New York, 320 pp.

Aurelio, M.A., Forbes, M.T., Taguibao, K.J.L. et al., 2013. Middle to Late Cenozoic tectonic events in south and central Palawan (Philippines) and their implications to the evolution of the south- eastern margin of South China Sea: Evidence from onshore structural and offshore seismic data. Marine and Petroleum Geology. doi:10.1016/j.marpetgeo.2013.12.002.

Barckhausen, U., Engels, M., Franke, D., Ladage, S., Pubellier, M., 2014. Evolution of the South China Sea: Revised ages for breakup and seafloor spreading. Marine and Petroleum Geology. doi:10.1016/j.marpetgeo.2014.02.022.

Birkeland, P.W., 1984. Soils and geomorphology. Oxford University Press, Oxford, 310 pp.

Biscaye, P.E., 1965. Mineralogy and sedimentation of recent deep-sea clay in the Atlantic Ocean and adjacent seas and oceans. Geological Society of America Bulletin, 76: 803-832.

Boulay, S., Colin, C., Trentesaux, A., Clain, S., Liu, Z., Lauer-Leredde, C., 2007. Sedimentary responses to the Pleistocene climatic variations recorded in the South China Sea. Quaternary Research, 68: 162-172.

Briais, A., Patriat, P., Tapponnier, P., 1993. Updated interpretation of magnetic anomalies and seafloor spreading stages in the South China Sea: implications for the Tertiary tectonics of Southeast Asia. Journal of Geophysical Research, 98: 6299-6328. doi:10.1029/92JB02280.

Burbank, D.W., Blythe, A.E., Putkonen, J., Pratt-Sitaula, B., Gabet, E., Oskins, M., Barros, A., Ojha, T.P., 2003. Decoupling of erosion and precipitation in the Himalayas. Nature, 426: 652-655.

Carter, A., Roques, D., Bristow, C., Kinny, P.D., 2001. Understanding Mesozoic accretion in Southeast Asia: Significance of Triassic thermotectonism (Indosinian orogeny) in Vietnam. Geology, 29: 211-214.

Carter, A., Roques, D., Bristow, C.S., 2000. Denudation history of onshore central Vietnam: constraints on the Cenozoic evolution of the western margin of the South China Sea. Tectonophysics, 322: 265-277.

Chen, C.H., Lee, T., 1990. A Nd-Sr isotopic study on river sediments of Taiwan. Proceedings of the Geological Society of China, 33(4): 339-350.

Chu, P.C., Li, R., 2000. South China Sea Isopycnal-Surface Circulation. Journal of Physical Oceanography, 30: 2419-2438.

Clark, M.K., House, M.A., Royden, L.H., Whipple, K.X., Burchfiel, B.C., Zhang, X., Tang, W., 2005. Late Cenozoic uplift of southeastern Tibet. Geology, 33(6): 525-528. doi: 10.1130/G21265.1.

Clark, M.K., Schoenbohm, L.M., Royden, L.H., Whipple, K.X., Burchfiel, B.C., Zhang, X., Tang, W., Wang, E., Chen, L., 2004. Surface uplift, tectonics, and erosion of eastern Tibet from large-scale drainage patterns. Tectonics, 23, TC1006. doi:10.1029/2002TC001402.

Clift, P.D., 2006. Controls on the erosion of Cenozoic Asia and the flux of clastic sediment to the ocean. Earth and Planetary Science Letters, 241(3-4): 571-580. 
Clift, P.D., 2015. Assessing effective provenance methods for fluvial sediment in the South China Sea. In: Clift, P.D., Harff, J., Wu, J., Yan, Q. (Eds.), River-dominated shelf sediments of East Asian seeds, 429, Geological Society, London, doi:10.1144/SP429.3.

Clift, P.D., Blusztajn, J., Nguyen, D.A., 2006a. Large-scale drainage capture and surface uplift in eastern Tibet-SW China before $24 \mathrm{Ma}$ inferred from sediments of the Hanoi Basin, Vietnam. Geophysical Research Letters, 33(L19403). doi:10.1029/2006GL027772.

Clift, P.D., Carter, A., Campbell, I.H., Pringle, M., Hodges, K.V., Lap, N.V., Allen, C.M., 2006b. Thermochronology of mineral grains in the Song Hong and Mekong Rivers, Vietnam. Geophysics, Geochemistry, Geosystems, 7(Q10005). doi:10.1029/2006GC001336.

Clift, P.D., Lee, G.H., Nguyen, A.D., Barckhausen, U., Hoang, V.L., Sun, Z., 2008. Seismic evidence for a Dangerous Grounds mini-plate: No extrusion origin for the South China Sea. Tectonics, 27(TC3008). doi:10.1029/2007TC002216.

Clift, P.D., Vannucchi, P., Phipps Morgan, J., 2009. Crustal redistribution, crust-mantle recycling and Phanerozoic evolution of the continental crust. Earth Science Reviews, 97: 80-104. doi:10.1016/j.earscirev.2009.10.003.

Clift, P.D., Wan, S., Blusztajn, J., 2014. Reconstructing Chemical Weathering, Physical Erosion and Monsoon Intensity since $25 \mathrm{Ma}$ in the northern South China Sea: A review of competing proxies. Earth-Science Reviews, 130: 86-102. doi:10.1016/j.earscirev.2014.01.002.

Colin, C., Siani, G., Sicre, M.-A., Liu, Z., 2010. Impact of the East Asian monsoon rainfall changes on the erosion of the Mekong River basin over the past 25,000 yr. Marine Geology, 271(1-2): 84-92. doi:10.1016/j.margeo.2010.01.013.

Cullen, A., Reemst, P., Henstra, G., Gozzard, S., Ray, A., 2010. Rifting of the South China Sea: new perspectives. Petroleum Geoscience, 16: 273-282.

Cung, T.C., Dorobek, S., Richter, C., Flower, M., Kikawa, E., Nguyen, Y.T., McCabe, R., 1998. Paleomagnetism of Late Neogene basalts in Vietnam and Thailand: Implications for the post-Miocene tectonic history of Indochina. In: Flower, M.F.J., Chung, S.-L., Lo, C.-H., Lee, T.Y. (Eds.), Mantle Dynamics and Plate Interactions in East Asia. Geodynamic Series, 27, American Geophysical Union, Washington, D.C., pp. 289-299,

Deniel, C., Pin, C., 2001. Single-stage method for the simultaneous isolation of lead and strontium from silicate samples for isotopic measurements. Analytica Chimica Acta, 426(1): 95-103.

DePaolo, D.J., Wasserburg, G.J., 1976. Nd isotopic variations and petrogenetic models. Geophysical Research Letters, 3(5): 249-252.

Ding, W., Li, J., Clift, P.D., IODP Expedition 349 Scientists, 2016. Spreading dynamics and sedimentary process of the Southwest Sub-basin, South China Sea: Constraints from multi-channel seismic data and IODP Expedition 349. Journal of Asian Earth Sciences, 115(1): 97-113. doi:10.1016/j.jseaes.2015.09.013.

Edzwald, J.K., O'Melia, C.R., 1975. Clay distributions in recent estuarine sediments. Clays and Clay Minerals, 23: 39-44.

Fang, G., Fang, W., Fang, Y., Wang, K., 1998. A survey of studies on the South China Sea upper ocean circulation. Acta Oceanography of Taiwanica, 37(1): 1-16.

Fang, Z., Zhao, J.-X., McCulloch, M.T., 1992. Geochemical and Nd isotopic study of Palaeozoic bimodal volcanics in Hainan Island, South China-Implications for rifting tectonics and mantle reservoirs. Lithos, 29(1-2): 127-139. doi:10.1016/0024-4937(92)90037-Y. 
Fletcher, C.J.N., Chan, L.S., Sewell, R.J., Campbell, S.D.G., Davis, D.W., Zhu, J., 2004. Basement heterogeneity in the Cathaysia crustal block, southeast China. In: Malpas, J., Fletcher, C.J.N., Ali, J.R., Aitchison, J.C. (Eds.), Aspects of the Tectonic Evolution of China. Special Publication, 226, Geological Society, London, pp. 145-155, doi:10.1144/GSL.SP.2004.226.01.08.

Garçon, M., Chauvel, C., France-Lanord, C., Huyghe, P., Lavé, J., 2013. Continental sedimentary processes decouple $\mathrm{Nd}$ and $\mathrm{Hf}$ isotopes. Geochimica et Cosmochimica Acta, 121: 177-195. doi:doi.org/10.1016/j.gca.2013.07.027.

Garçon, M., Chauvel, C., France-Lanord, C., Limonta, M., Garzanti, E., 2014. Which minerals control the $\mathrm{Nd}-\mathrm{Hf}-\mathrm{Sr}-\mathrm{Pb}$ isotopic compositions of river sediments? Chemical Geology, 364: 42-55. doi:10.1016/j.chemgeo.2013.11.018.

Gibbs, R.J., 1977. Clay mineral segregation in the marine environment. Journal of Sediment Petrology, 47: 237-243.

Hall, R., 2002. Cenozoic geological and plate tectonic evolution of SE Asia and the SW Pacific: computer-based reconstructions and animations. Journal of Asian Earth Sciences, 20: 353-434.

Hamilton, P.J., O'Nions, R.K., Bridgwater, D., Nutman, A., 1983. Sm-Nd Studies of Archean Metasediments and Metavolcanics from West Greenland and Their Implications for the Earths Early History. Earth and Planetary Science Letters, 62(2): 263-272.

Haq, B.U., Hardenbol, J., Vail, P.R., 1987. Chronology of fluctuating sea levels since the Triassic. Science, 235: 1156-1167.

Hayes, D.E., Lewis, S.D., 1984. A geophysical study of the Manila Trench, Luzon, Philippines; 1, Crustal structure, gravity, and regional tectonic evolution. Journal of Geophysical Research, 89: 9171-9195.

Hillier, S., 1995. Erosion, sedimentation, and sedimentary origin of clays. In: Velde, B. (Ed.), Clays and the environment, Springer Verlag, Berlin, pp. 162-219,

Hinz, K., Fritsch, J., Kempter, E.H.K., Mohammad, A.M., Meyer, J., Mohamed, D., Vosberg, H., Weber, J., Benavidez, J., 1989. Thrust tectonics along the north-western continental margin of Sabah/Borneo. Geologische Rundschau, 78(3): 705-730.

Hiscott, R.N., 1984. Ophiolitic source rocks for Taconic-age flysch: trace element evidence. Geological Society of America Bulletin, 95, : 1261-1267.

Hoang, L.V., Wu, F.Y., Clift, P.D., Wysocka, A., Swierczewska, A., 2009. Evaluating the evolution of the Red River system based on in-situ U-Pb dating and Hf isotope analysis of zircons. Geochemistry Geophysics Geosystems, 10(Q11008). doi:10.1029/2009GC002819.

Hoang, N., Flower, M., 1998. Petrogenesis of Cenozoic Basalts from Vietnam: Implication for Origins of a 'Diffuse Igneous Province'. Journal of Petrology, 39(3): 369-395. doi:10.1093/petroj/39.3.369.

Hodder, A.P.W., Naish, T.R., Nelson, C.S., 1993. A two-stage model for the formation of smectite from detrital volcanic glass under shallow-marine conditions. Marine Geology, 109(3-4): 279-285. doi:10.1016/0025-3227(93)90066-5.

Honza, E., John, J., Banda, R.M., 2000. An imbrication model for the Rajang accretionary complex in Sarawak, Borneo. Journal of Asian Earth Sciences, 18(6): 751-759.

$\mathrm{Hu}, \mathrm{B} ., \mathrm{Li}, \mathrm{J} ., \mathrm{Cui}$, R. et al., 2014. Clay mineralogy of the riverine sediments of Hainan Island, South China Sea: Implications for weathering and provenance. Journal of Asian Earth Sciences, 96: 84-92. doi:10.1016/j.jseaes.2014.08.036. 
Hu, D., Clift, P.D., Böning, P., Hannigan, R., Hillier, S., Blusztajn, J., Wang, S., Fuller, D.Q., 2013. Holocene evolution in weathering and erosion patterns in the Pearl River delta. Geochemistry Geophysics Geosystems, 14. doi:10.1002/ggge.20166.

Hutchison, C.S., 2004. Marginal basin evolution; the southern South China Sea. Marine and Petroleum Geology, 21(9): 1129-1148. doi:10.1016/j.marpetgeo.2004.07.002.

Hutchison, C.S., 2005. Geology of North-West Borneo: Sarawak, Brunei and Sabah. Elsevier, Amsterdam, $448 \mathrm{pp}$.

Hutchison, C.S., Vijayan, V.R., 2010. What are the Spratly Islands? Journal of Asian Earth Sciences, 39(5): 371-385. doi:10.1016/ j.jseaes.2010.04.013.

Jahn, B.M., Zhou, X.H., Li, J.L., 1990. Formation and tectonic evolution of Southeastern China and Taiwan: Isotopic and geochemical constraints. Tectonophysics, 183: 145-160.

Jonell, T.N., Clift, P.D., Hoang, L.V., Hoang, T., Carter, A., Wittmann, H., Böning, P., Pahnke, K., Rittenour, T., 2016. Controls on Erosion Patterns and Sediment Transport in a Monsoonal, Tectonically Quiescent Drainage, Song Gianh, Central Vietnam. Basin Research: 1-25. doi: 10.1111/bre.12199.

Knittel, U., Defant, M.J., Raczek, I., 1988. Recent enrichment in the source region of arc magmas from Luzon island, Philippines: $\mathrm{Sr}$ and $\mathrm{Nd}$ isotopic evidence. Geology, 16(1): 73-76. doi: 10.1130/0091-7613(1988)016.

Lan, C.Y., Lee, C.-S., Shen, J.J.-S., Lu, C.Y., Mertzman, S.A., Wu, T.-W., 2002. Nd -Sr isotopic composition and geochemistry of sediments from Taiwan and their implications. Western Pacific Earth Sciences, 2(2): 205-222.

Lavé, J., Avouac, J.P., 2001. Fluvial incision and tectonic uplift across the Himalaya of central Nepal. Journal of Geophysical Research, 106: 26,561-26,592. doi: 10.1029/2001JB000359.

Lepvrier, C., Maluski, H., Vu, V.T., Leyreloup, A., Phan, T.T., Vuong, N.V., 2004. The Early Triassic Indosinian orogeny in Vietnam (Truong Son Belt and Kontum Massif ); implications for the geodynamic evolution of Indochina. Tectonophysics, 393: 87-118. doi:10.1016/j.tecto.2004.07.030.

Li, C.-F., Lin, J., Kulhanek, D.K. et al., 2015. Site U1433. Proceedings of the International Ocean Discovery Program, 349. doi:10.14379/iodp.proc.349.105.2015.

Li, C.-F., Xu, X., Expedition 349 Scientific Party, 2014. Ages and magnetic structures of the South China Sea constrained by deep tow magnetic surveys and IODP Expedition 349. Geochemistry, Geophysics, Geosystems, 15: 4958-4983. doi:10.1002/ 2014GC005567.

Li, L., Clift, P.D., Nguyen, H.T., 2013. The sedimentary, magmatic and tectonic evolution of the Southwestern South China Sea revealed by seismic stratigraphic analysis. Marine Geophysical Research, 34: 393-406. doi:10.1007/s11001-013-9171-y.

Liu, J.P., Xue, Z., Ross, K., H, J.W., Yang, Z.S., Li, A.C., Gao, S., 2009a. Fate of sediments delivered to the sea by Asian large rivers: Long-distance transport and formation of remote alongshore clinothems. The Sedimentary Record, 7(4): 4-9.

Liu, Z., Colin, C., Huang, W., Le, K.P., Tong, S., Chen, Z., Trentesaux, A., 2007. Climatic and tectonic controls on weathering in south China and Indochina Peninsula: Clay mineralogical and geochemical investigations from the Pearl, Red, and Mekong drainage basins. Geochemistry Geophysics Geosystems, 8, Q05005. doi:10.1029/2006GC001490.

Liu, Z., Colin, C., Li, X. et al., 2010. Clay mineral distribution in surface sediments of the northeastern South China Sea and surrounding fluvial drainage basins: Source and transport. Marine Geology, 277: 48-60. doi:10.1016/j.margeo.2010.08.010. 
Liu, Z., Colin, C., Trentesaux, A., Siani, G., Frank, N., Blamart, D., Farid, S., 2005. Late Quaternary climatic control on erosion and weathering in the eastern Tibetan Plateau and the Mekong Basin. Quaternary Research, 63: 316-328.

Liu, Z., Tuo, S., Colin, C. et al., 2008. Detrital fine-grained sediment contribution from Taiwan to the northern South China Sea and its relation to regional ocean circulation. Marine Geology, 255(3-4): 149-155.

Liu, Z., Wang, H., Hantoro, W.S., Sathiamurthy, E., Colin, C., Zhao, Y., Li, J., 2012. Climatic and tectonic controls on chemical weathering in tropical Southeast Asia (Malay Peninsula, Borneo, and Sumatra). Chemical Geology, 291: 1-12.

Liu, Z., Zhao, Y., Colin, C., Siringan, F.P., Wu, Q., 2009b. Chemical weathering in Luzon, Philippines from clay mineralogy and major-element geochemistry of river sediments. Applied Geochemistry, 24: 2195-2205.

Liu, Z., Zhao, Y., Colin, C. et al., 2016a. Source-to-sink transport processes of fluvial sediments in the South China Sea. in press. doi:10.1016/j.earscirev.2015.08.005.

Liu, Z., Zhao, Y., Colin, C. et al., 2016b. Source-to-sink transport processes of fluvial sediments in the South China Sea. Earth Science Reviews, 153: 238-273. doi:10.1016/j.earscirev.2015.08.005.

Lupker, M., France- Lanord, C., Lavé, J., Bouchez, J., Galy, V., Métivier, F., Gaillardet, J., Lartiges, B., Mugnier, J.L., 2011. A Rouse- based method to integrate the chemical composition of river sediments: Application to the Ganga basin. Journal of Geophysical Research, 116(F04012). doi:10.1029/2010JF001947.

McLennan, S.M., 1993. Weathering and global denudation. The Journal of Geology, 101: 295303.

Metcalfe, I., 1996. Pre-Cretaceous evolution of SE Asian terranes. In: Hall, R., Blundell, D.J. (Eds.), Tectonic evolution of SE Asia. Special Publication, 106, Geological Society London, pp. 97-122,

Métivier, F., Gaudemer, Y., Tapponnier, P., Klein, M., 1999. Mass accumulation rates in Asia during the Cenozoic. Geophysical Journal International, 137(2): 280-318.

Mielke, J.E., 1979. Composition of the Earth's crust and distribution of the elements. In: Siegel, F.R. (Ed.), Review of Research on Modern Problems in Geochemistry, UNESCO, Paris, pp. 13-36,

Milliman, J.D., Farnsworth, K.L., 2011. River Discharge to the Coastal Ocean: a Global Synthesis, 384. Cambridge University Press, Cambridge.

Milliman, J.D., Farnsworth, K.L., Albertin, C.S., 1999. Flux and fate of fluvial sediments leaving large islands in the East Indies. Journal of Sea Research, 41(1-2): 97-107.

Milliman, J.D., Syvitski, J.P.M., 1992. Geomorphic/tectonic control of sediment discharge to the ocean; the importance of small mountainous rivers. Journal of Geology, 100: 525-544.

Molengraaff, G.A.E., Weber, M., 1919. Het verband tusschen den plistoceenen ijstijd en het ontstaan der Soenda-zee (Java- en Zuid-Chmeesche Zee) en de invloed daarvan op de verspreidmg der koraalriffen en op de land-en zoetwater-fauna. Verslag Van de Gewone Vergaderingen der Wis-En Natuurkundige Afdeeling, 28: 497-544.

Morley, C.K., 2002. A tectonic model for the Tertiary evolution of strike-slip faults and rift basins in SE Asia. Tectonophysics, 347(4): 189-215.

Murray, M.R., Dorobek, S.L., 2004. Sediment supply, tectonic subsidence, and basin-filling patterns across the southwestern South China Sea during Pliocene to Recent time. In: Clift, P., Wang, P., Kuhnt, W., Hayes, D. (Eds.), Continent-ocean interactions within east 
Asian marginal seas. Geophysical Monograph, 149, American Geophysical Union, Washington, DC, pp. 235-254,

Nagarajan, R., Roy, P.D., Jonathan, M.P., Lozano, R., Kessler, F.L., Prasanna, M.V., 2014. Geochemistry of Neogene sedimentary rocks from Borneo Basin, East Malaysia:Paleoweathering, provenance and tectonic setting. Chemie der Erde, 74: 139-146. doi:10.1016/j.chemer.2013.04.003.

Nesbitt, H.W., Markovics, G., Price, R.C., 1980. Chemical processes affecting alkalis and alkaline earths during continental weathering. Geochimica et Cosmochimica Acta, 44: 1659-1666.

Nesbitt, H.W., Young, G.M., 1982. Early Proterozoic climates and plate motions inferred from major element chemistry of lutites. Nature, 299(5885): 715-717.

Petschick, R., Kuhn, G., Gingele, F., 1996. Clay mineral distribution in surface sediments of the South Atlantic: sources, transport, and relation to oceanography. Marine Geology, 130: 203-229.

Replumaz, A., Tapponnier, P., 2003. Reconstruction of the deformed collision zone between India and Asia by backward motion of lithospheric blocks. Journal of Geophysical Research, 108, 2285(B6). doi:10.1029/2001JB000661.

Riebe, C.S., Kirchner, J.W., Granger, D.E., Finkel, R.C., 2001. Strong tectonic and weak climatic control of long-term chemical weathering rates. Geology, 29: 511-514.

Robinson, R.A.J., Brezina, C.A., Parrish, R.R. et al., 2013. Large rivers and orogens: The evolution of the Yarlung Tsangpo-Irrawaddy system and the eastern Himalayan syntaxis. Gondwana Research. doi:10.1016/j.gr.2013.07.002.

Ru, K., Pigott, J.D., 1986. Episodic rifting and subsidence in the South China Sea. AAPG Bulletin, 70(9): 1136-1155.

Savva, D., Pubellier, M., Franke, D., Chamot-Rooke, N., Meresse, F., Steuer, S., Auxietre, J.L., 2014. Different expressions of rifting on the South China Seas margins. Marine and Petroleum Geology, 58: 579-598.

Shi, X., Kohn, B., Spencer, S., Guo, X., Li, Y., Yang, X., Shi, H., Gleadow, A., 2011. Cenozoic denudation history of southern Hainan Island, South China Sea: Constraints from low temperature thermochronology. Tectonophysics, 504: 100-115.

Simons, W., Socquet, A., Vigny, C. et al., 2007. A decade of GPS in Southeast Asia: Resolving Sundaland motion and boundaries. Journal of Geophysical Research, 112(B06420). doi:10.1029/2005JB003868.

Singh, S.K., Sarin, M.M., France-Lanord, C., 2005. Chemical erosion in the eastern Himalaya; major ion composition of the Brahmaputra and d13C of dissolved inorganic carbon. Geochimica et Cosmochimica Acta, 69(14): 3573-3588.

Su, D., White, N., McKenzie, D., 1989. Extension and subsidence of the Pearl River mouth basin, northern South China Sea. Basin Research, 2: 205-222.

Tapponnier, P., Peltzer, G., Le Dain, G., A. Y., Armijo, R., Cobbold, P.R., 1982. Propagating extrusion tectonics in Asia: New insights from simple experiments with plasticine. Geology, 10: 611-616.

Taylor, B., Hayes, D.E., 1983. Origin and history of the South China Sea basin. In: Hayes, D.E. (Ed.), The Tectonic and Geologic Evolution of the Southeast Asian Seas and Islands, 27, American Geophysical Union, Washington, D.C., pp. 23-56,

Taylor, S.R., McLennan, S.M., 1985. The continental crust: Its composition and evolution. Blackwell Scientific, Palo Alto, CA, 328 pp. 
Thirlwall, M.F., 1991. Long-term reproducibility of multicollector $\mathrm{Sr}$ and $\mathrm{Nd}$ isotope ratio analysis. Chemical Geology: Isotope Geoscience section, 94(2): 85-104.

Thiry, M., 2000. Palaeoclimatic interpretation of clay minerals in marine deposits; an outlook from the continental origin. Earth-Science Reviews, 49(1-4): 201-221.

Tu, K., Flower, M.F.J., Carlson, R.W., Xie, G., Chen, C.-Y., Zhang, M., 1992. Magmatism in the South China Basin: 1. Isotopic and trace-element evidence for an endogenous Dupal mantle component. Chemical Geology, 97(1-2): 47-63. doi:10.1016/00092541(92)90135-R.

Wan, S., Li, A., Clift, P.D., Jiang, H., 2006. Development of the East Asian summer monsoon; evidence from the sediment record in the South China Sea since $8.5 \mathrm{Ma}$. Palaeogeography, Palaeoclimatology, Palaeoecology, 241: 139-159.

Wan, S., Li, A., Clift, P.D., Stuut, J.-B.W., 2007. Development of the East Asian monsoon: Mineralogical and sedimentologic records in the northern South China Sea since $20 \mathrm{Ma}$. Palaeogeography, Palaeoclimatology, Palaeoecology, 254(3-4): 561-582.

Wang, E., Kirby, E., Furlong, K.P., Soest, M.v., Xu, G., Shi, X., Kamp, P.J.J., Hodges, K.V., 2012. Two-phase growth of high topography in eastern Tibet during the Cenozoic. Nature Geoscience, 5: 640-645. doi:10.1038/ngeo1538.

Wang, J., Yin, A., Harrison, T.M., Grove, M., Zhang, Y., Xie, G., 2001. A tectonic model for Cenozoic igneous activities in the eastern Indo-Asian collision zone. Earth and Planetary Science Letters, 188(1-2): 123-133.

Wei, G., Liu, Y., Ma, J., Xie, L., Chen, J., Deng, W., Tang, S., 2012. Nd, Sr isotopes and elemental geochemistry of surface sediments from the South China Sea: Implications for Provenance Tracing. Marine Geology, 319-322: 21-34. doi:10.1016/j.margeo.2012.05.007.

White, W.M., Patchett, J., 1984. Hf-Nd-Sr isotopes and incompatible element abundances in island arcs: Implications for magma origins and crust-mantle evolution. Earth and Planetary Science Letters, 67(2): 167-185. doi:10.1016/0012-821X(84)90112-2.

Wobus, C.W., Tucker, G.E., Anderson, R.S., 2010. Does climate change create distinctive patterns of landscape incision? Journal of Geophysical Research, 115(F04008). doi:10.1029/2009JF001562.

Zachos, J., Pagani, M., Sloan, L., Thomas, E., Billups, K., 2001. Trends, rythms and abberations in global climate $65 \mathrm{Ma}$ to Present. Science, 292: 686-693.

Zheng, H., Clift, P.D., Tada, R., Jia, J.T., He, M.Y., Wang, P., 2013. A Pre-Miocene Birth to the Yangtze River. Proceedings of the National Academy of Sciences: 1-6. doi:10.1073/pnas.1216241110. 


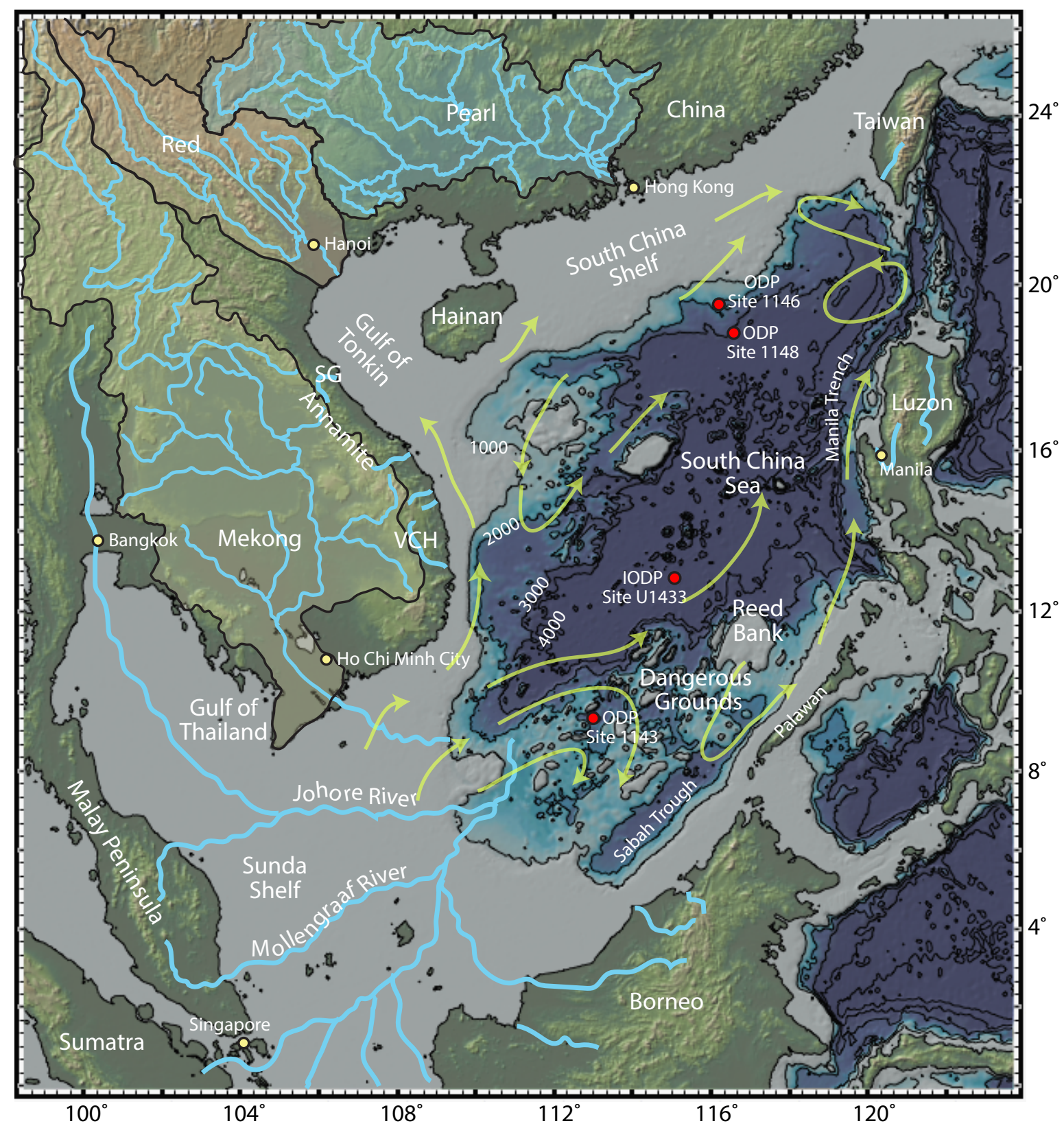

Figure 1

Liu et al. 


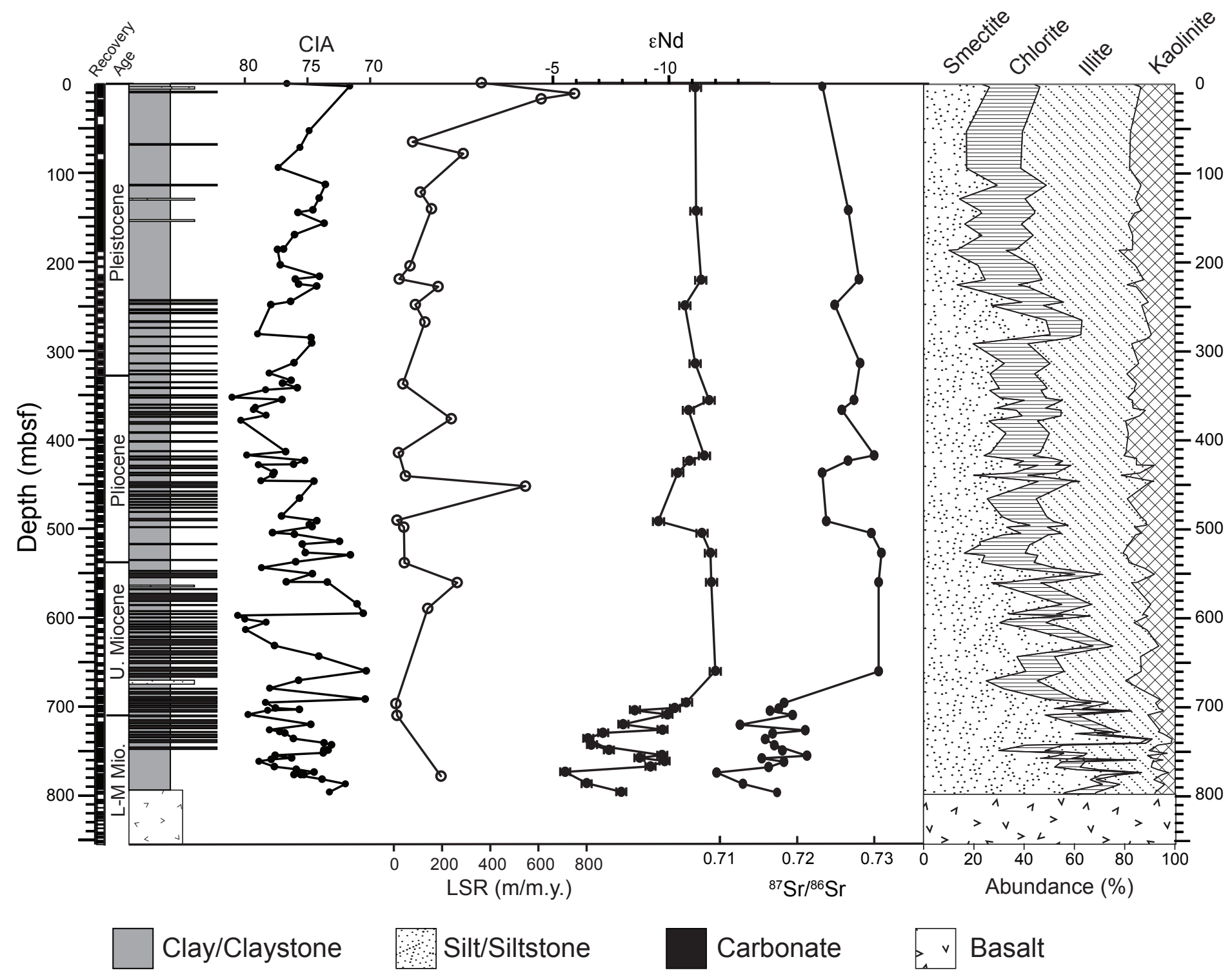

Figure 2

Liu et al. 


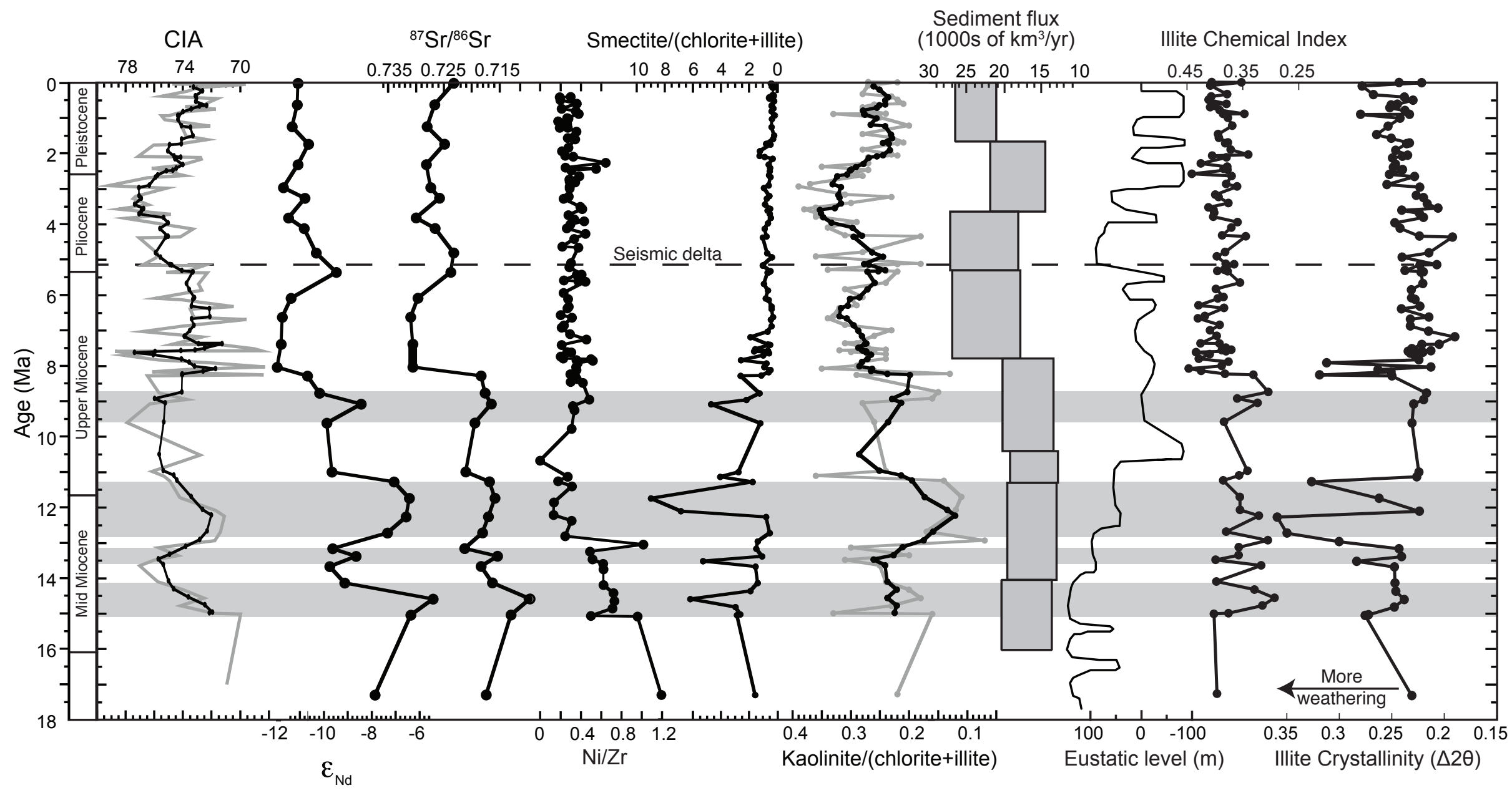

Figure 3 Liu et al. 
(A)
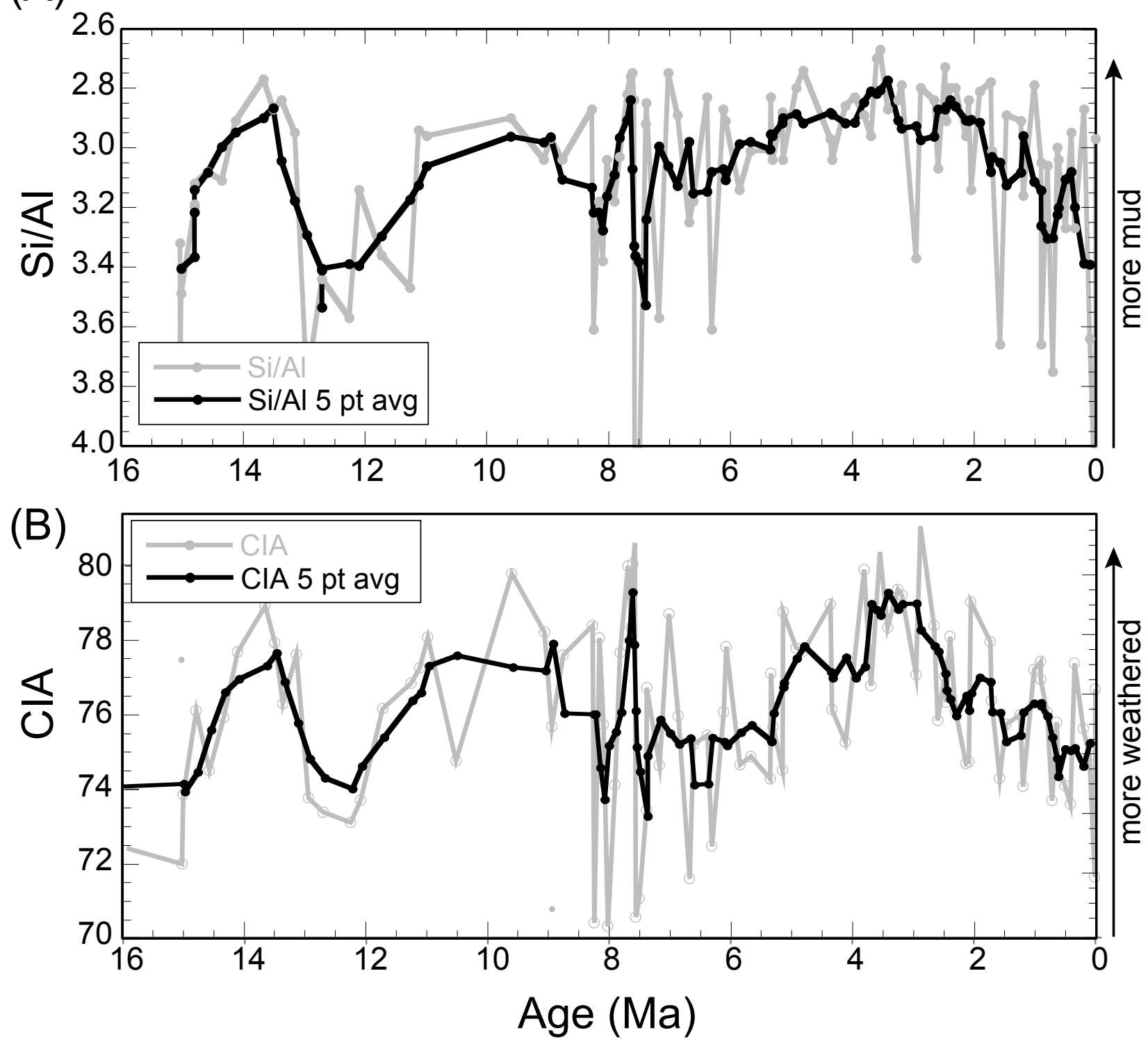

Figure 4

Liu et al. 

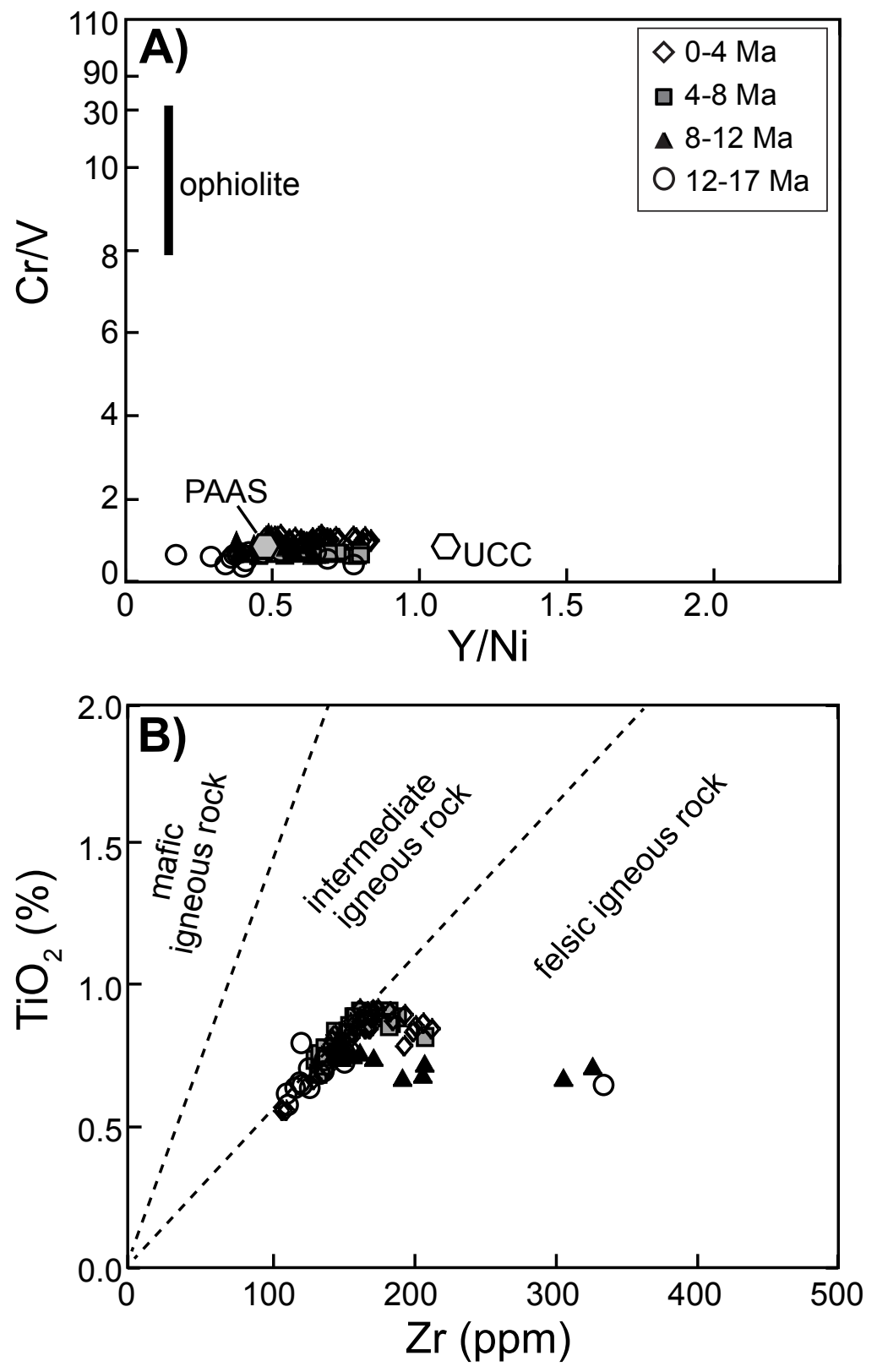

Liu et al.

Figure 5 


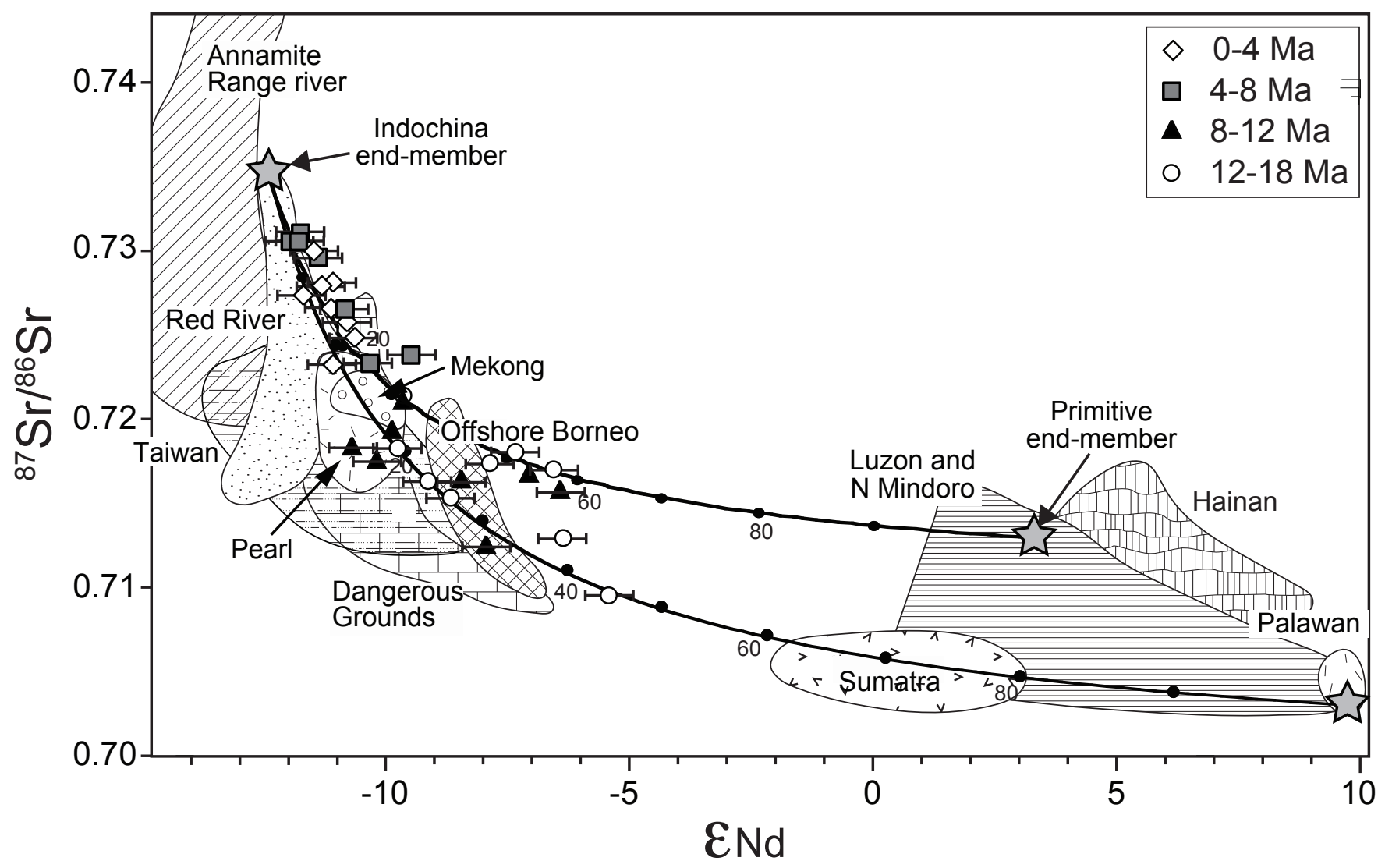

Figure 6 Liu et al. 

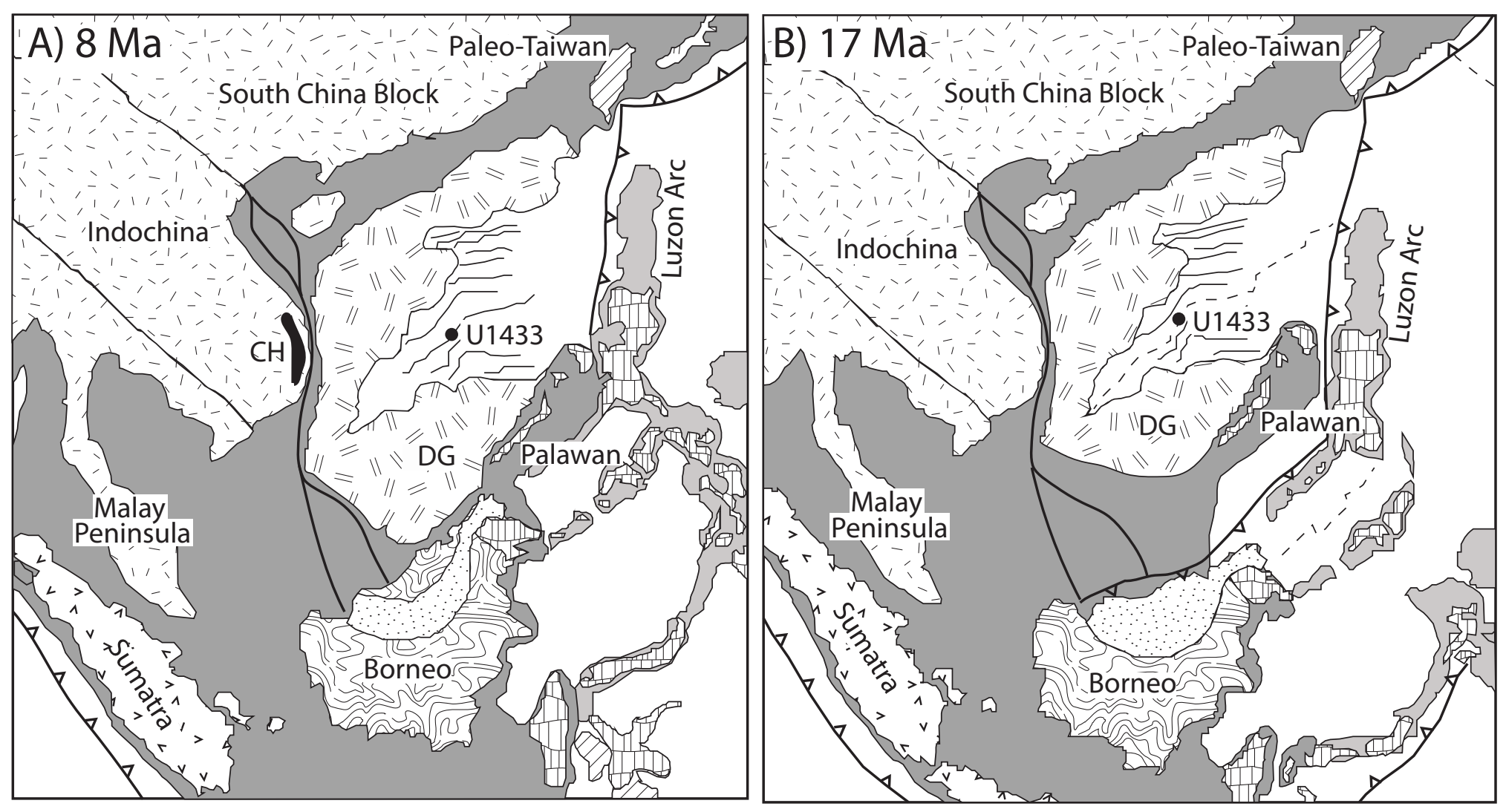

Figure 7

Liu et al. 

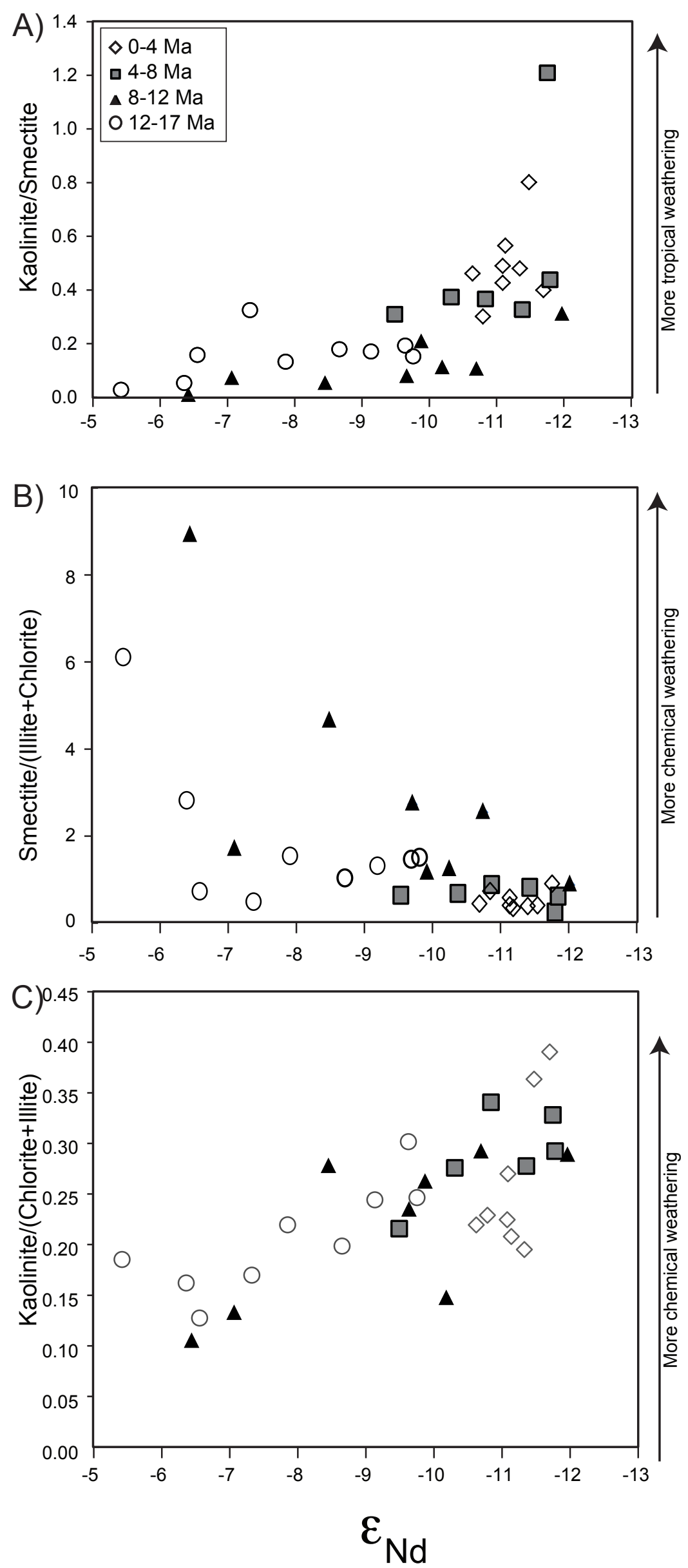

Figure 8

Liu et al. 


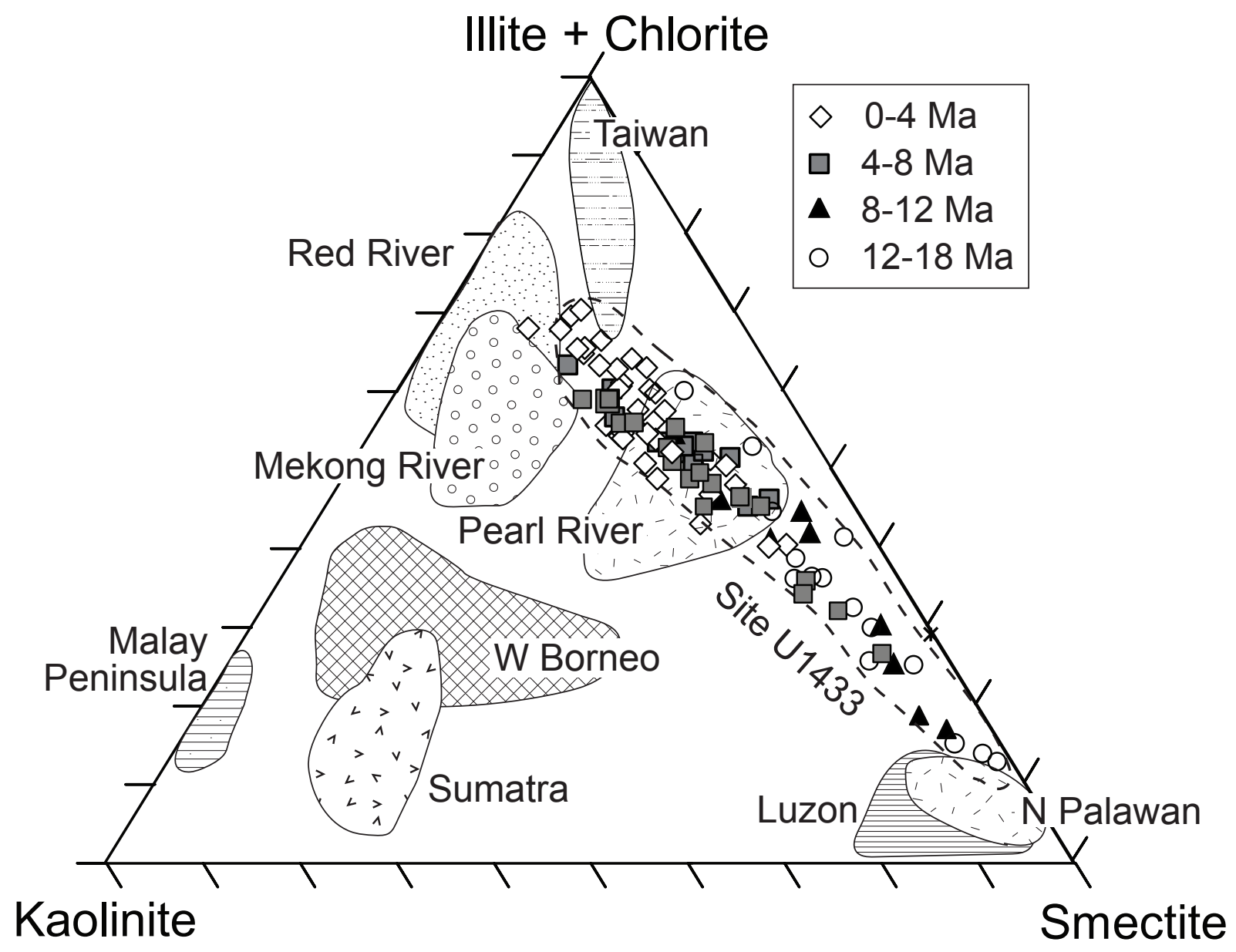

Figure 9

Liu et al. 


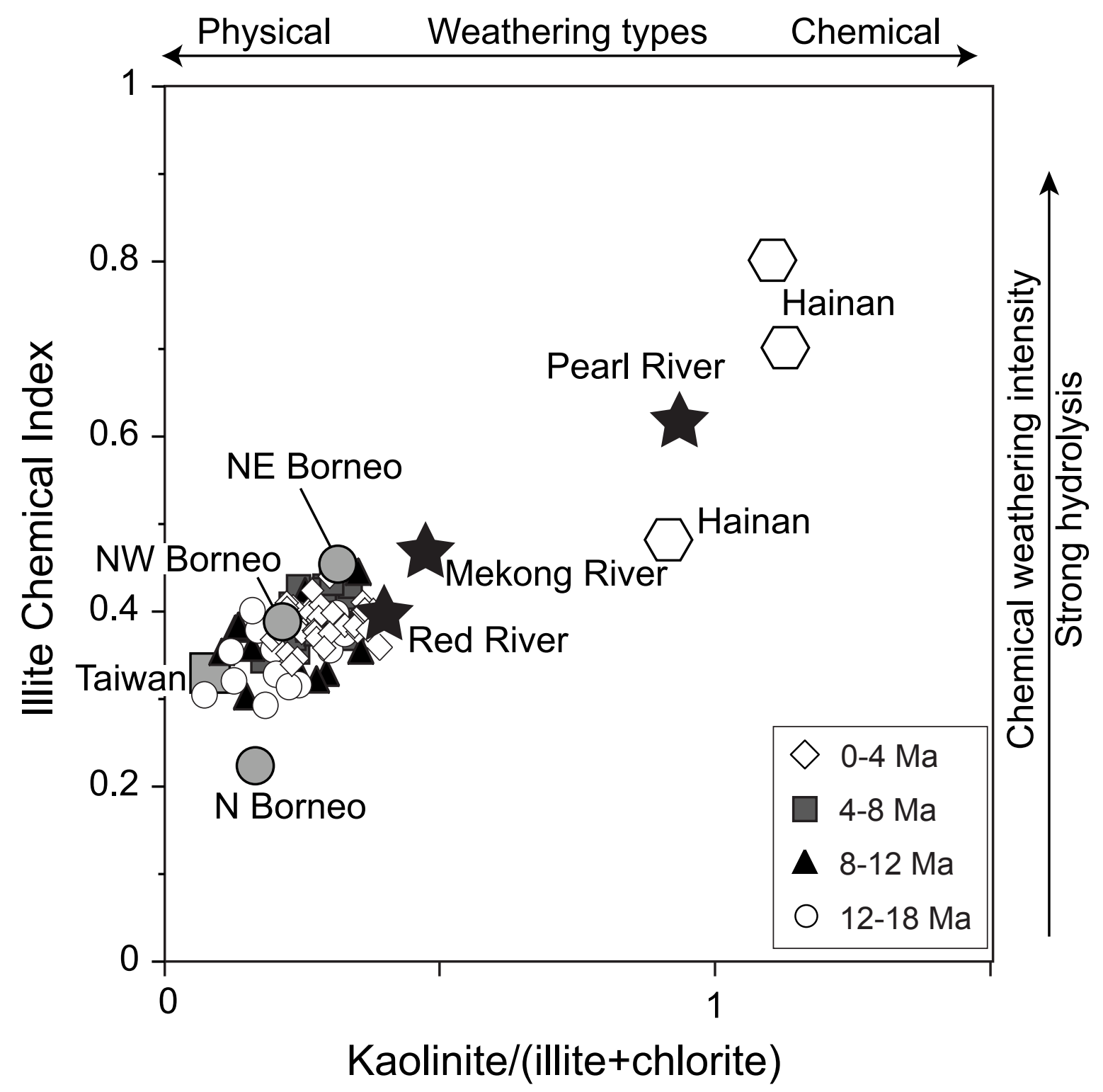

Figure 10

Liu et al. 


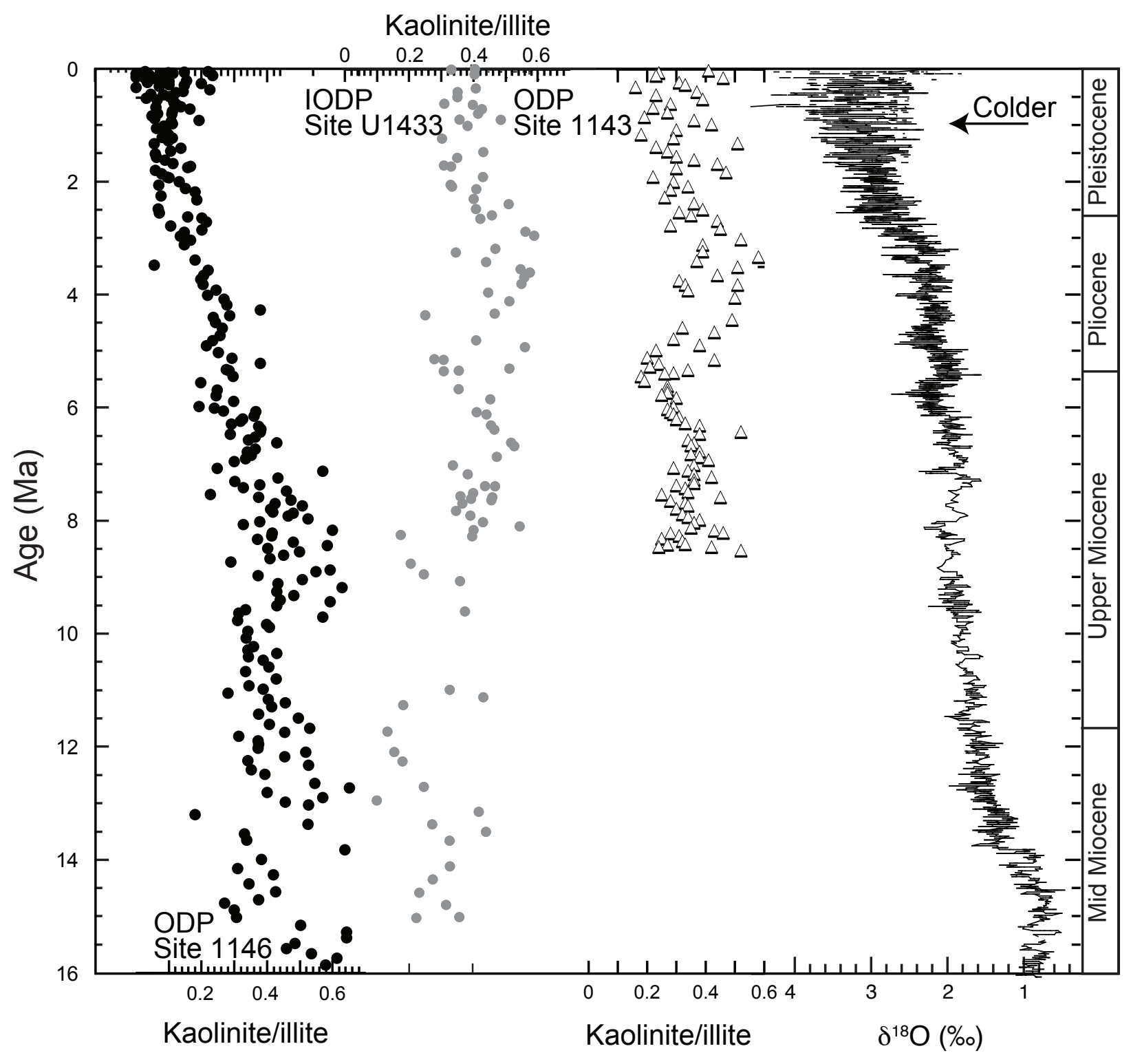

Figure 11 Liu et al. 


\begin{tabular}{|c|c|c|c|c|c|c|c|c|c|c|c|c|c|c|c|c|c|c|c|c|}
\hline Sample & $\begin{array}{l}\text { Age } \\
\text { (Ma) }\end{array}$ & $\mathrm{SiO}_{2}$ & $\mathrm{TiO}_{2}$ & $\mathrm{Al}_{2} \mathrm{O}_{3}$ & $\mathrm{Fe}_{2} \mathrm{O}_{3}$ & $\mathrm{MnO}$ & $\mathrm{MgO}$ & $\mathrm{CaO}$ & $\mathrm{Na}_{2} \mathrm{O}$ & $\mathrm{K}_{2} \mathrm{O}$ & $\mathrm{P}_{2} \mathrm{O}_{5}$ & $\mathrm{Sr}$ & $\mathrm{Zr}$ & $\mathrm{Cu}$ & $\mathrm{Cr}$ & V & $\mathrm{Y}$ & $\mathrm{Ni}$ & Sc & $\mathrm{Ba}$ \\
\hline \multicolumn{21}{|l|}{ IODP U1433A } \\
\hline $1 \mathrm{H}-1,50-52 \mathrm{~cm}$ & 0.00 & 55.97 & 0.85 & 18.82 & 6.99 & 0.06 & 2.36 & 0.58 & 0.68 & 3.28 & 0.13 & 99.8 & 162 & 40.3 & 98.3 & 139 & 29.8 & 48.8 & 17.5 & 639 \\
\hline $1 \mathrm{H}-3,50-52 \mathrm{~cm}$ & 0.01 & 65.21 & 0.79 & 15.50 & 5.30 & 0.05 & 1.89 & 0.69 & 1.13 & 2.79 & 0.12 & 108.9 & 194 & 32.9 & 85.0 & 112 & 27.1 & 37.5 & 14.2 & 569 \\
\hline $6 \mathrm{H}-5,60-64 \mathrm{~cm}$ & 0.10 & 62.79 & 0.86 & 17.25 & 6.13 & 0.05 & 1.97 & 0.56 & 0.90 & 3.04 & 0.12 & 103.3 & 203 & 34.5 & 88.2 & 125 & 34.0 & 40.4 & 16.2 & 473 \\
\hline $8 \mathrm{H}-5,48-52 \mathrm{~cm}$ & 0.20 & 55.27 & 0.87 & 19.26 & 7.36 & 0.09 & 2.66 & 0.63 & 0.74 & 3.54 & 0.13 & 103.7 & 157 & 39.7 & 110.6 & 154 & 31.4 & 56.3 & 17.7 & 621 \\
\hline $11 \mathrm{H}-1,50-52 \mathrm{~cm}$ & 0.34 & 59.94 & 0.88 & 18.33 & 5.55 & 0.04 & 1.91 & 0.43 & 0.71 & 3.15 & 0.12 & 95.8 & 186 & 31.4 & 96.5 & 125 & 30.5 & 39.1 & 16.8 & 481 \\
\hline $13 \mathrm{H}-1,50-54 \mathrm{~cm}$ & 0.41 & 55.37 & 0.84 & 18.77 & 6.82 & 0.07 & 2.42 & 0.96 & 0.78 & 3.41 & 0.12 & 115.0 & 152 & 36.9 & 103.2 & 142 & 28.1 & 53.6 & 17.6 & 607 \\
\hline $14 \mathrm{H}-5,50-54 \mathrm{~cm}$ & 0.50 & 57.14 & 0.85 & 17.46 & 8.48 & 0.06 & 2.24 & 0.73 & 0.82 & 3.17 & 0.13 & 105.5 & 167 & 35.9 & 102.2 & 133 & 30.3 & 63.2 & 16.1 & 572 \\
\hline $16 \mathrm{H}-1,50-54 \mathrm{~cm}$ & 0.62 & 57.16 & 0.92 & 18.81 & 6.58 & 0.05 & 2.38 & 0.68 & 0.76 & 3.61 & 0.13 & 101.7 & 176 & 35.2 & 94.4 & 141 & 29.2 & 46.8 & 17.3 & 576 \\
\hline $16 \mathrm{H}-3,50-54 \mathrm{~cm}$ & 0.63 & 57.88 & 0.85 & 19.28 & 6.76 & 0.06 & 2.34 & 0.67 & 0.76 & 3.41 & 0.13 & 105.7 & 170 & 39.7 & 100.7 & 146 & 30.6 & 47.4 & 17.1 & 545 \\
\hline $17 \mathrm{H}-5,50-54 \mathrm{~cm}$ & 0.71 & 61.79 & 0.85 & 16.46 & 5.97 & 0.05 & 1.91 & 0.59 & 0.97 & 2.96 & 0.12 & 101.8 & 214 & 29.6 & 92.4 & 122 & 31.1 & 37.9 & 15.1 & 505 \\
\hline $19 \mathrm{H}-1,50-52 \mathrm{~cm}$ & 0.79 & 57.34 & 0.86 & 18.74 & 6.65 & 0.06 & 2.23 & 0.51 & 0.74 & 3.46 & 0.11 & 94.8 & 170 & 34.5 & 109.0 & 143 & 30.0 & 45.4 & 17.6 & 545 \\
\hline \multicolumn{21}{|l|}{ IODP U1433B } \\
\hline $2 \mathrm{R}-1,34-36 \mathrm{~cm}$ & 0.90 & 62.45 & 0.87 & 17.04 & 5.42 & 0.04 & 1.67 & 0.37 & 0.82 & 2.84 & 0.11 & 95.7 & 208 & 34.6 & 84.7 & 123 & 32.9 & 39.7 & 15.4 & 441 \\
\hline $2 \mathrm{R}-1,85-87 \mathrm{~cm}$ & 0.90 & 60.79 & 0.91 & 19.92 & 7.01 & 0.06 & 2.22 & 0.48 & 0.75 & 3.43 & 0.12 & 102.0 & 184 & 38.7 & 91.4 & 138 & 34.2 & 49.7 & 18.2 & 521 \\
\hline $4 \mathrm{R}-1,24-28 \mathrm{~cm}$ & 1.01 & 54.07 & 0.87 & 19.35 & 8.33 & 0.07 & 2.66 & 0.36 & 0.60 & 3.75 & 0.12 & 87.5 & 159 & 38.5 & 120.4 & 149 & 30.1 & 57.0 & 18.5 & 586 \\
\hline $5 \mathrm{R}-3,60-64 \mathrm{~cm}$ & 1.19 & 59.33 & 0.91 & 18.77 & 7.16 & 0.06 & 2.57 & 0.74 & 0.90 & 3.46 & 0.14 & 107.3 & 173 & 32.5 & 119.0 & 148 & 31.6 & 46.9 & 17.9 & 604 \\
\hline $5 \mathrm{R}-5,60-64 \mathrm{~cm}$ & 1.23 & 56.84 & 0.89 & 19.55 & 7.67 & 0.07 & 2.73 & 0.51 & 0.66 & 3.85 & 0.11 & 93.7 & 163 & 43.7 & 125.4 & 167 & 32.7 & 56.4 & 18.8 & 588 \\
\hline $6 \mathrm{R}-2,100-104 \mathrm{~cm}$ & 1.47 & 56.06 & 0.90 & 19.41 & 7.05 & 0.06 & 2.40 & 0.60 & 0.72 & 3.64 & 0.12 & 101.3 & 165 & 31.8 & 110.5 & 149 & 31.3 & 45.7 & 17.8 & 613 \\
\hline $6 \mathrm{R}-4,30-34 \mathrm{~cm}$ & 1.57 & 62.03 & 0.84 & 16.95 & 5.71 & 0.05 & 2.04 & 0.53 & 0.90 & 3.14 & 0.11 & 98.7 & 201 & 30.4 & 88.2 & 120 & 30.3 & 43.1 & 15.3 & 521 \\
\hline $8 \mathrm{R}-2,110-114 \mathrm{~cm}$ & 1.71 & 56.81 & 0.82 & 18.90 & 7.32 & 0.04 & 2.54 & 0.56 & 0.60 & 3.55 & 0.09 & 100.8 & 157 & 31.8 & 96.3 & 144 & 26.8 & 38.7 & 17.6 & 561 \\
\hline $8 \mathrm{R}-5,50-54 \mathrm{~cm}$ & 1.73 & 55.17 & 0.81 & 19.85 & 7.01 & 0.08 & 2.40 & 0.44 & 0.50 & 3.69 & 0.10 & 92.9 & 144 & 44.8 & 99.6 & 147 & 28.6 & 46.7 & 18.2 & 575 \\
\hline $10 \mathrm{R}-3,50-54 \mathrm{~cm}$ & 1.91 & 41.93 & 0.56 & 14.92 & 5.90 & 0.21 & 2.43 & 13.08 & 0.50 & 2.38 & 0.56 & 722.7 & 111 & 111.0 & 97.2 & 126 & 36.4 & 71.5 & 16.1 & 588 \\
\hline $12 \mathrm{R}-1,36-38 \mathrm{~cm}$ & 2.05 & 57.58 & 0.79 & 18.32 & 7.98 & 0.04 & 2.53 & 0.26 & 0.54 & 3.24 & 0.09 & 99.6 & 146 & 38.0 & 102.2 & 137 & 28.7 & 36.5 & 17.3 & 555 \\
\hline $12 \mathrm{R}-4,53-55 \mathrm{~cm}$ & 2.08 & 52.70 & 0.71 & 18.55 & 7.36 & 0.05 & 2.57 & 1.21 & 0.47 & 3.03 & 0.45 & 175.5 & 140 & 105.3 & 99.5 & 156 & 42.5 & 77.3 & 19.3 & 539 \\
\hline $13 \mathrm{R}-1,78-82 \mathrm{~cm}$ & 2.13 & 55.50 & 0.86 & 18.72 & 7.18 & 0.10 & 2.41 & 0.77 & 0.71 & 3.49 & 0.11 & 109.7 & 161 & 37.6 & 107.3 & 148 & 29.5 & 49.0 & 17.5 & 649 \\
\hline $15 \mathrm{R}-3,60-64 \mathrm{~cm}$ & 2.30 & 54.44 & 0.77 & 19.43 & 7.23 & 0.07 & 2.47 & 0.98 & 0.46 & 3.28 & 0.21 & 141.6 & 147 & 66.4 & 84.1 & 143 & 32.4 & 56.4 & 18.1 & 571 \\
\hline $16 \mathrm{R}-4,110-114 \mathrm{~cm}$ & 2.39 & 56.59 & 0.84 & 20.20 & 6.54 & 0.05 & 2.19 & 0.45 & 0.55 & 3.64 & 0.09 & 104.0 & 157 & 32.9 & 97.7 & 148 & 28.8 & 45.0 & 17.4 & 607 \\
\hline $17 \mathrm{R}-3,100-104 \mathrm{~cm}$ & 2.46 & 56.14 & 0.91 & 19.29 & 6.83 & 0.06 & 2.30 & 0.61 & 0.59 & 3.60 & 0.09 & 110.7 & 171 & 37.4 & 107.3 & 145 & 31.7 & 49.6 & 18.0 & 648 \\
\hline $17 \mathrm{R}-5,114-118 \mathrm{~cm}$ & 2.48 & 54.54 & 0.83 & 19.99 & 7.50 & 0.05 & 2.56 & 0.56 & 0.63 & 3.61 & 0.09 & 135.1 & 146 & 51.8 & 104.4 & 147 & 27.8 & 50.0 & 17.7 & 664 \\
\hline $18 \mathrm{R}-2,100-104 \mathrm{~cm}$ & 2.59 & 58.91 & 0.91 & 19.17 & 6.82 & 0.05 & 2.36 & 0.63 & 0.69 & 3.54 & 0.11 & 110.6 & 168 & 35.9 & 97.3 & 146 & 29.9 & 49.0 & 17.5 & 662 \\
\hline $18 \mathrm{R}-4,50-54 \mathrm{~cm}$ & 2.65 & 55.26 & 0.85 & 19.49 & 7.08 & 0.08 & 2.38 & 0.36 & 0.52 & 3.58 & 0.09 & 101.2 & 161 & 44.7 & 106.9 & 156 & 30.1 & 46.5 & 18.3 & 654 \\
\hline
\end{tabular}




\begin{tabular}{|c|c|c|c|c|c|c|c|c|c|c|c|c|c|c|c|c|c|c|c|c|}
\hline Sample & $\begin{array}{l}\text { Age } \\
(\mathrm{Ma}) \\
\end{array}$ & $\mathrm{SiO}_{2}$ & $\mathrm{TiO}_{2}$ & $\mathrm{Al}_{2} \mathrm{O}_{3}$ & $\mathrm{Fe}_{2} \mathrm{O}_{3}$ & $\mathrm{MnO}$ & $\mathrm{MgO}$ & $\mathrm{CaO}$ & $\mathrm{Na}_{2} \mathrm{O}$ & $\mathrm{K}_{2} \mathrm{O}$ & $\mathrm{P}_{2} \mathrm{O}_{5}$ & $\mathrm{Sr}$ & $\mathrm{Zr}$ & $\mathrm{Cu}$ & $\mathrm{Cr}$ & V & $\mathrm{Y}$ & $\mathrm{Ni}$ & $\mathrm{Sc}$ & $\mathrm{Ba}$ \\
\hline \multicolumn{21}{|l|}{ IODP U1433B } \\
\hline $19 \mathrm{R} 3,71-75 \mathrm{~cm}$ & 2.88 & 57.11 & 0.92 & 20.36 & 6.61 & 0.04 & 2.18 & 0.21 & 0.44 & 3.39 & 0.09 & 99.9 & 163 & 34.9 & 111.0 & 154 & 31.8 & 45.6 & 18.0 & 664 \\
\hline $19 \mathrm{R}-5,55-59 \mathrm{~cm}$ & 2.95 & 60.26 & 0.90 & 17.87 & 6.07 & 0.04 & 2.04 & 0.61 & 0.52 & 3.09 & 0.08 & 108.0 & 195 & 26.5 & 90.8 & 125 & 32.7 & 44.7 & 16.3 & 588 \\
\hline $20 \mathrm{R}-4,90-94 \mathrm{~cm}$ & 3.18 & 55.89 & 0.81 & 20.04 & 7.39 & 0.07 & 2.51 & 0.23 & 0.60 & 3.56 & 0.10 & 116.8 & 149 & 82.3 & 115.8 & 160 & 29.0 & 59.3 & 18.6 & 719 \\
\hline $20 \mathrm{R}-6,40-44 \mathrm{~cm}$ & 3.25 & 55.46 & 0.77 & 19.55 & 7.22 & 0.06 & 2.58 & 0.27 & 0.54 & 3.43 & 0.09 & 126.9 & 143 & 65.9 & 89.2 & 149 & 28.3 & 59.2 & 17.7 & 661 \\
\hline $21 \mathrm{R}-3,141-143 \mathrm{~cm}$ & 3.42 & 56.83 & 0.89 & 19.80 & 6.76 & 0.05 & 2.45 & 0.32 & 0.51 & 3.76 & 0.08 & 118.5 & 166 & 37.1 & 106.4 & 159 & 29.9 & 46.2 & 17.8 & 685 \\
\hline $22 \mathrm{R}-1,23-25 \mathrm{~cm}$ & 3.54 & 53.76 & 0.79 & 20.10 & 8.15 & 0.10 & 2.58 & 0.31 & 0.44 & 3.35 & 0.09 & 104.5 & 143 & 67.1 & 90.8 & 145 & 29.7 & 47.7 & 18.3 & 671 \\
\hline $23 \mathrm{R}-3,145-149 \mathrm{~cm}$ & 3.60 & 48.60 & 0.67 & 17.98 & 6.60 & 0.06 & 2.58 & 5.08 & 0.38 & 2.97 & 0.35 & 570.4 & 130 & 84.0 & 96.9 & 137 & 37.9 & 56.5 & 16.5 & 761 \\
\hline $25 \mathrm{R}-5,55-59 \mathrm{~cm}$ & 3.69 & 56.39 & 0.89 & 19.08 & 6.72 & 0.05 & 2.09 & 0.58 & 0.55 & 3.52 & 0.09 & 122.3 & 165 & 28.5 & 88.7 & 142 & 30.1 & 48.8 & 17.3 & 662 \\
\hline $26 \mathrm{R}-1,50-54 \mathrm{~cm}$ & 3.80 & 56.59 & 0.89 & 19.59 & 7.07 & 0.05 & 2.23 & 0.27 & 0.46 & 3.41 & 0.09 & 112.2 & 173 & 32.2 & 107.8 & 146 & 30.6 & 45.2 & 18.6 & 689 \\
\hline $26 \mathrm{R}-3,50-54 \mathrm{~cm}$ & 3.96 & 42.27 & 0.56 & 14.96 & 6.60 & 0.66 & 2.33 & 10.65 & 0.35 & 2.71 & 0.70 & 677.3 & 108 & 154.7 & 90.4 & 129 & 38.8 & 48.1 & 14.4 & 523 \\
\hline $26 \mathrm{R}-5,50-54 \mathrm{~cm}$ & 4.11 & 55.51 & 0.78 & 19.43 & 6.98 & 0.07 & 2.42 & 0.96 & 0.51 & 3.51 & 0.23 & 153.3 & 144 & 59.8 & 106.3 & 147 & 35.2 & 48.1 & 17.9 & 582 \\
\hline $27 \mathrm{R}-1,40-44 \mathrm{~cm}$ & 4.33 & 58.06 & 0.89 & 19.10 & 6.34 & 0.04 & 2.19 & 0.56 & 0.57 & 3.72 & 0.09 & 140.3 & 172 & 28.7 & 93.6 & 142 & 30.1 & 37.6 & 17.5 & 693 \\
\hline $27 \mathrm{R}-2,15-19 \mathrm{~cm}$ & 4.36 & 54.93 & 0.74 & 18.50 & 7.24 & 0.04 & 2.51 & 0.33 & 0.47 & 3.28 & 0.09 & 198.2 & 132 & 83.0 & 85.9 & 136 & 26.7 & 49.4 & 16.4 & 688 \\
\hline $28 \mathrm{R}-1,62-66 \mathrm{~cm}$ & 4.80 & 55.38 & 0.79 & 20.19 & 6.99 & & 2.35 & 0.57 & & 3.67 & 0.10 & & 148 & & & 149 & & & 17.7 & 668 \\
\hline $28 \mathrm{R}-3,48-52 \mathrm{~cm}$ & 4.92 & 54.50 & 0.88 & 19.45 & 7.87 & 0.09 & 2.38 & 0.68 & 0.45 & 3.29 & 0.09 & 147.8 & 165 & 26.8 & 102.4 & 139 & 30.8 & 47.7 & 17.1 & 665 \\
\hline $29 \mathrm{R}-1,20-24 \mathrm{~cm}$ & 5.14 & 55.74 & 0.79 & 18.32 & 7.42 & 0.04 & 2.57 & 0.31 & 0.49 & 3.31 & 0.09 & 197.1 & 147 & 55.1 & 97.5 & 154 & 27.1 & 60.1 & 17.1 & 636 \\
\hline $29 \mathrm{R}-1,71-75 \mathrm{~cm}$ & 5.15 & 55.08 & 0.84 & 19.12 & 6.81 & 0.05 & 2.51 & 1.09 & 0.47 & 3.49 & 0.08 & 170.3 & 146 & 33.2 & 102.9 & 141 & 28.5 & 52.8 & 17.5 & 670 \\
\hline $31 \mathrm{R}-1,50-52 \mathrm{~cm}$ & 5.30 & & 0.90 & 18.82 & 7.07 & 0.07 & 2.36 & & & 3.52 & 0.10 & 149.0 & 170 & 30.2 & & 146 & & 39.7 & 17.8 & 658 \\
\hline $33 \mathrm{R}-1,101-103 \mathrm{~cm}$ & 5.34 & 56.28 & 0.76 & 19.91 & 7.13 & 0.09 & 2.66 & 0.33 & 0.77 & 3.74 & 0.10 & 221.0 & 141 & 63.8 & 103.8 & 150 & 29.3 & 52.7 & 18.7 & 650 \\
\hline $33 \mathrm{R}-5,106-108 \mathrm{~cm}$ & 5.35 & 55.20 & 0.69 & 18.34 & 6.59 & 0.04 & 2.60 & 1.01 & 0.48 & 3.45 & 0.25 & 124.6 & 134 & 87.4 & 104.3 & 144 & 34.8 & 59.6 & 17.8 & 398 \\
\hline $34 \mathrm{R}-1,26-28 \mathrm{~cm}$ & 5.67 & 57.46 & 0.84 & 19.07 & 6.22 & 0.04 & 2.40 & 0.77 & 0.55 & 3.79 & 0.11 & 115.0 & 155 & 32.4 & 94.7 & 143 & 27.4 & 35.7 & 17.4 & 519 \\
\hline $34 \mathrm{R}-3,26-28 \mathrm{~cm}$ & 5.85 & 57.45 & 0.87 & 18.29 & 6.81 & 0.09 & 2.35 & 0.84 & 0.61 & 3.40 & 0.09 & 136.8 & 168 & 32.1 & 111.1 & 139 & 29.7 & 45.9 & 16.6 & 552 \\
\hline $35 \mathrm{R}-1,39-41 \mathrm{~cm}$ & 6.08 & 56.87 & 0.89 & 19.54 & 6.46 & 0.04 & 2.52 & 0.53 & 0.48 & 3.52 & 0.09 & 107.5 & 159 & 41.4 & 107.0 & 160 & 29.0 & 44.4 & 18.1 & 509 \\
\hline $35 \mathrm{R}-3,46-48 \mathrm{~cm}$ & 6.12 & 55.60 & 0.86 & 19.35 & 6.75 & 0.05 & 2.49 & 0.69 & 0.53 & 3.65 & 0.12 & 121.8 & 167 & 38.1 & 111.8 & 147 & 29.6 & 44.9 & 17.7 & 556 \\
\hline $36 \mathrm{R}-1,40-44 \mathrm{~cm}$ & 6.31 & 63.15 & 0.89 & 17.50 & 6.13 & 0.07 & 2.31 & 0.79 & 0.85 & 3.53 & 0.11 & 109.0 & 190 & 28.3 & 79.7 & 126 & 29.7 & 38.3 & 16.0 & 536 \\
\hline $36 \mathrm{R}-3,48-52 \mathrm{~cm}$ & 6.38 & 54.18 & 0.84 & 19.15 & 7.66 & 0.08 & 2.42 & 0.88 & 0.51 & 3.50 & 0.10 & 144.6 & 155 & 36.3 & 114.7 & 143 & 30.5 & 48.4 & 17.8 & 552 \\
\hline $37 \mathrm{R}-3,78-82 \mathrm{~cm}$ & 6.61 & 58.92 & 0.91 & 18.51 & 6.59 & 0.06 & 2.33 & 0.58 & 0.66 & 3.66 & 0.10 & 101.6 & 179 & 25.8 & 90.6 & 136 & 30.1 & 41.9 & 17.1 & 522 \\
\hline $37 \mathrm{R}-5,78-82 \mathrm{~cm}$ & 6.68 & 58.44 & 0.91 & 17.98 & 6.75 & 0.07 & 2.38 & 1.09 & 0.74 & 3.63 & 0.10 & 154.4 & 184 & 27.2 & 83.5 & 133 & 30.6 & 38.7 & 16.1 & 554 \\
\hline $38 \mathrm{R}-3,94-98 \mathrm{~cm}$ & 6.86 & 54.27 & 0.86 & 18.80 & 6.97 & 0.06 & 2.36 & 0.68 & 0.57 & 3.49 & 0.10 & 133.5 & 156 & 31.3 & 102.7 & 143 & 30.7 & 45.6 & 17.9 & 546 \\
\hline $39 \mathrm{R}-1,78-82 \mathrm{~cm}$ & 7.02 & 55.82 & 0.78 & 20.30 & 7.76 & 0.05 & 2.57 & 0.29 & 0.48 & 3.86 & 0.10 & 337.2 & 140 & 41.2 & 90.5 & 143 & 28.9 & 63.8 & 18.1 & 565 \\
\hline $39 \mathrm{R}-6,66-69 \mathrm{~cm}$ & 7.17 & 61.43 & 0.87 & 17.23 & 5.62 & 0.04 & 2.15 & 0.70 & 0.68 & 3.19 & 0.11 & 139.2 & 186 & 30.1 & 91.1 & 125 & 28.4 & 39.4 & 15.4 & 491 \\
\hline $40 \mathrm{R}-5,49-53 \mathrm{~cm}$ & 7.38 & 56.07 & 0.91 & 19.67 & 6.61 & 0.05 & 2.45 & 0.49 & 0.54 & 3.86 & 0.10 & 109.6 & 164 & 33.0 & 98.5 & 151 & 28.3 & 43.7 & 18.2 & 510 \\
\hline $40 \mathrm{R}-6,5-9 \mathrm{~cm}$ & 7.39 & 56.11 & 0.89 & 19.22 & 7.01 & 0.07 & 2.47 & 1.28 & 0.55 & 3.43 & 0.10 & 186.2 & 161 & 29.3 & 109.1 & 147 & 29.0 & 49.2 & 17.3 & 544 \\
\hline
\end{tabular}

Liu et al. 


\begin{tabular}{|c|c|c|c|c|c|c|c|c|c|c|c|c|c|c|c|c|c|c|c|c|}
\hline Sample & $\begin{array}{c}\text { Age } \\
(\mathrm{Ma})\end{array}$ & $\mathrm{SiO}_{2}$ & $\mathrm{TiO}_{2}$ & $\mathrm{Al}_{2} \mathrm{O}_{3}$ & $\mathrm{Fe}_{2} \mathrm{O}_{3}$ & $\mathrm{MnO}$ & $\mathrm{MgO}$ & $\mathrm{CaO}$ & $\mathrm{Na}_{2} \mathrm{O}$ & $\mathrm{K}_{2} \mathrm{O}$ & $\mathrm{P}_{2} \mathrm{O}_{5}$ & $\mathrm{Sr}$ & $\mathrm{Zr}$ & $\mathrm{Cu}$ & $\mathrm{Cr}$ & V & $\mathrm{Y}$ & $\mathrm{Ni}$ & $\mathrm{Sc}$ & $\mathrm{Ba}$ \\
\hline \multicolumn{21}{|l|}{ IODP U1433B } \\
\hline $43 \mathrm{R}-2,119-122 \mathrm{~cm}$ & 7.51 & 64.56 & 0.86 & 15.72 & 5.33 & 0.05 & 2.00 & 0.72 & 0.93 & 3.28 & 0.10 & 148.9 & 184 & 26.5 & 76.6 & 116 & 29.9 & 37.4 & 14.3 & 486 \\
\hline $44 \mathrm{R}-3,63-65 \mathrm{~cm}$ & 7.56 & 64.12 & 0.82 & 15.29 & 5.07 & 0.05 & 1.85 & 0.97 & 0.86 & 2.95 & 0.12 & 155.4 & 209 & 35.5 & 82.5 & 115 & 33.0 & 47.7 & 13.2 & 503 \\
\hline $44 \mathrm{R}-5,48-50 \mathrm{~cm}$ & 7.58 & 56.03 & 0.76 & 19.71 & 7.29 & 0.08 & 2.60 & 0.19 & 0.57 & 3.19 & 0.09 & 462.0 & 135 & 87.7 & 93.7 & 140 & 27.9 & 67.6 & 17.4 & 532 \\
\hline $45 \mathrm{R}-1,34-38 \mathrm{~cm}$ & 7.61 & 55.62 & 0.77 & 20.20 & 7.31 & 0.11 & 2.52 & 0.22 & 0.46 & 3.59 & 0.10 & 254.3 & 142 & 87.9 & 121.5 & 159 & 30.1 & 50.6 & 18.8 & 617 \\
\hline $45 \mathrm{R}-3,89-93 \mathrm{~cm}$ & 7.63 & 54.90 & 0.76 & 19.88 & 6.92 & 0.05 & 2.46 & 0.20 & 0.67 & 3.72 & 0.08 & 399.1 & 145 & 76.7 & 95.3 & 137 & 30.1 & 75.3 & 17.8 & 607 \\
\hline $46 \mathrm{R}-2,86-90 \mathrm{~cm}$ & 7.69 & 56.67 & 0.78 & 20.08 & 7.02 & 0.05 & 2.60 & 0.21 & 0.52 & 3.51 & 0.09 & 428.1 & 139 & 126.4 & 104.3 & 141 & 28.5 & 51.2 & 17.9 & 617 \\
\hline $48 \mathrm{R}-1,103-107 \mathrm{~cm}$ & 7.82 & 56.58 & 0.72 & 18.68 & 7.09 & 0.07 & 2.62 & 0.27 & 0.67 & 3.50 & 0.07 & 571.8 & 138 & 45.0 & 96.2 & 124 & 26.7 & 48.7 & 16.7 & 640 \\
\hline $49 \mathrm{R}-3,61-65 \mathrm{~cm}$ & 7.91 & 56.93 & 0.75 & 17.89 & 6.10 & 0.04 & 2.10 & 1.00 & 0.46 & 3.40 & 0.08 & 185.2 & 140 & 58.0 & 100.5 & 149 & 25.5 & 49.8 & 16.3 & 527 \\
\hline $51 \mathrm{R}-1,35-38 \mathrm{~cm}$ & 8.02 & 55.76 & 0.79 & 18.36 & 5.69 & 0.06 & 2.12 & 2.00 & 0.37 & 3.24 & 0.10 & 230.3 & 149 & 41.3 & 97.9 & 127 & 28.3 & 44.0 & 15.9 & 565 \\
\hline $52 \mathrm{R}-1,118-121 \mathrm{~cm}$ & 8.10 & 59.73 & 0.76 & 17.66 & 6.18 & 0.05 & 1.98 & 0.59 & 0.66 & 3.22 & 0.09 & 213.1 & 159 & 64.5 & 108.0 & 128 & 27.2 & 55.0 & 16.0 & 529 \\
\hline $53 \mathrm{R}-1,40-42 \mathrm{~cm}$ & 8.16 & 59.21 & 0.78 & 18.64 & 6.02 & 0.05 & 1.93 & 0.51 & 0.56 & 3.14 & 0.08 & 172.7 & 154 & 69.7 & 103.6 & 127 & 27.5 & 55.4 & 16.7 & 520 \\
\hline $54 \mathrm{R}-2,133-137 \mathrm{~cm}$ & 8.25 & 60.84 & 0.75 & 16.87 & 5.07 & 0.03 & 1.96 & 1.33 & 0.78 & 3.12 & 0.06 & 326.2 & 151 & 48.4 & 79.9 & 123 & 25.9 & 45.3 & 15.3 & 435 \\
\hline $54 \mathrm{R}-5,85-89 \mathrm{~cm}$ & 8.27 & 57.80 & 0.77 & 20.15 & 5.52 & 0.02 & 2.55 & 0.36 & & 3.47 & 0.07 & 766.6 & 145 & & & 152 & 26.9 & & & 517 \\
\hline $55 \mathrm{R}-3,88-90 \mathrm{~cm}$ & 8.76 & 57.60 & 0.75 & 18.96 & 6.96 & 0.04 & 2.49 & 0.33 & 0.69 & 3.46 & 0.06 & 876.7 & 151 & 124.4 & 71.4 & 127 & 28.0 & 72.6 & 16.9 & 522 \\
\hline $55 \mathrm{R}-4,98-100 \mathrm{~cm}$ & 8.94 & 57.39 & 0.69 & 19.35 & 6.19 & 0.03 & 2.37 & 0.34 & 1.14 & 3.45 & 0.08 & 922.6 & 208 & 103.6 & 77.9 & 129 & 31.6 & 66.9 & 16.0 & 500 \\
\hline $55 \mathrm{R}-5,60-62 \mathrm{~cm}$ & 9.07 & 56.86 & 0.68 & 18.73 & 5.85 & 0.04 & 2.46 & 0.38 & 0.88 & 2.85 & 0.06 & 1032.0 & 194 & 59.9 & 73.5 & 103 & 24.7 & 65.2 & 15.0 & 730 \\
\hline $56 \mathrm{R}-1$, & 9.60 & 56.33 & 0.75 & 19.42 & 6.06 & 0.03 & 2.23 & 0.28 & 0.53 & 3.28 & 0.06 & 832.1 & 173 & 64.0 & 91.6 & 131 & 33.1 & 53.6 & 16.8 & 533 \\
\hline $57 \mathrm{R}-2,67-70 \mathrm{~cm}$ & 10.52 & 52.99 & 0.64 & 17.41 & 5.45 & 0.03 & 2.38 & 0.71 & 0.69 & 3.19 & & 832.8 & & 93.0 & & 114 & 27.9 & & 15.2 & 492 \\
\hline $57 \mathrm{R}-6,85-89 \mathrm{~cm}$ & 10.99 & & 0.73 & 20.00 & & 0.07 & & & & & 0.06 & & 209 & & & 142 & 32.7 & 56.5 & & 558 \\
\hline $58 \mathrm{R}-1,37-41 \mathrm{~cm}$ & 11.12 & 56.42 & 0.72 & 19.18 & 5.96 & 0.05 & 2.51 & 0.42 & 0.82 & 3.27 & 0.08 & 905.2 & 328 & 90.6 & 72.7 & 144 & 36.8 & 57.5 & 16.8 & 985 \\
\hline $58 \mathrm{R}-2,73-77 \mathrm{~cm}$ & 11.26 & 60.37 & 0.77 & 17.39 & 5.08 & 0.02 & 1.97 & 0.20 & 0.76 & 3.34 & 0.07 & 507.5 & 164 & 60.5 & 87.6 & 132 & 28.4 & 51.2 & 16.2 & 502 \\
\hline $58 \mathrm{R}-6,91-95 \mathrm{~cm}$ & 11.73 & 59.17 & 0.68 & 17.61 & 4.83 & 0.02 & 2.60 & 0.75 & 0.60 & 2.92 & 0.06 & 495.7 & 307 & 71.8 & 88.9 & 111 & 21.5 & 41.6 & 13.9 & 454 \\
\hline $59 \mathrm{R}-3,59-61 \mathrm{~cm}$ & 12.09 & 57.98 & 0.65 & 18.47 & 5.81 & 0.02 & 2.88 & 0.50 & 1.37 & 3.16 & 0.09 & & 335 & & 43.5 & 111 & 34.1 & 43.7 & 14.3 & 538 \\
\hline $59 \mathrm{R}-4,130-133 \mathrm{~cm}$ & 12.26 & 60.70 & 0.77 & 16.98 & & 0.04 & 1.97 & 0.67 & & 3.36 & 0.07 & 194.2 & 156 & 50.2 & & 128 & 25.7 & & 15.9 & 408 \\
\hline $60 \mathrm{R}-2,45-47 \mathrm{~cm}$ & 12.71 & 59.20 & 0.76 & 17.21 & 5.82 & 0.06 & 2.03 & 0.63 & 0.78 & 3.52 & 0.07 & 139.6 & 150 & 46.2 & 63.8 & 121 & 25.5 & 36.8 & 16.0 & 377 \\
\hline $60 \mathrm{R}-4,74-76 \mathrm{~cm}$ & 12.95 & 59.65 & 0.70 & 15.76 & 7.53 & 0.07 & 2.29 & 0.20 & 0.93 & 3.43 & 0.07 & 317.5 & 138 & 71.1 & 71.7 & 113 & 24.3 & 140.2 & 14.8 & 537 \\
\hline $60 \mathrm{R}-6,37-39 \mathrm{~cm}$ & 13.15 & 57.12 & 0.74 & 19.34 & 7.36 & 0.08 & 2.45 & 0.24 & 0.82 & 3.50 & 0.09 & 358.1 & 138 & 47.5 & 85.9 & 129 & 31.8 & 68.0 & 18.7 & 1188 \\
\hline $61 \mathrm{R}-1,102-104 \mathrm{~cm}$ & 13.37 & 54.88 & 0.73 & 19.33 & 7.44 & 0.16 & 2.28 & 0.28 & 0.91 & 3.70 & 0.09 & 317.1 & 152 & 79.7 & 83.2 & 122 & 30.8 & 78.4 & 17.2 & 1031 \\
\hline $61 \mathrm{R}-2,131-135 \mathrm{~cm}$ & 13.50 & 56.02 & 0.69 & 19.53 & 7.28 & 0.26 & 2.32 & 0.31 & 0.86 & 3.27 & 0.10 & 312.8 & 135 & 56.8 & 81.1 & 125 & 31.7 & 83.8 & 17.7 & 825 \\
\hline $61 \mathrm{R}-4,39-43 \mathrm{~cm}$ & 13.66 & 54.75 & 0.71 & 19.76 & 7.48 & 0.13 & 2.25 & 0.27 & 0.66 & 3.42 & 0.06 & 273.4 & 127 & 85.1 & 83.5 & 133 & 29.8 & 79.6 & 17.7 & 835 \\
\hline $62 \mathrm{R}-1,112-116 \mathrm{~cm}$ & 14.12 & 54.95 & 0.66 & 18.90 & 7.29 & 0.43 & 2.10 & 0.42 & 0.69 & 3.27 & 0.10 & 230.2 & 121 & 202.9 & 80.5 & 115 & 31.8 & 75.5 & 17.3 & 773 \\
\hline $62 \mathrm{R}-3,113-117 \mathrm{~cm}$ & 14.35 & 56.02 & 0.64 & 18.03 & 7.26 & 0.08 & 2.28 & 0.41 & 0.84 & 3.32 & 0.07 & 227.7 & 118 & 109.6 & 76.1 & 138 & 30.1 & 84.8 & 16.9 & 946 \\
\hline $62 \mathrm{R}-5,119-123 \mathrm{~cm}$ & 14.58 & 57.37 & 0.80 & 18.65 & 4.92 & 0.05 & 2.56 & 1.08 & 1.12 & 2.38 & 0.07 & 300.7 & 122 & 6077.8 & 67.3 & 174 & 30.3 & 89.1 & 22.0 & 767 \\
\hline
\end{tabular}

Liu et al. 


\begin{tabular}{|c|c|c|c|c|c|c|c|c|c|c|c|c|c|c|c|c|c|c|c|c|}
\hline Sample & $\begin{array}{c}\text { Age } \\
\text { (Ma) }\end{array}$ & $\mathrm{SiO}_{2}$ & $\mathrm{TiO}_{2}$ & $\mathrm{Al}_{2} \mathrm{O}_{3}$ & $\mathrm{Fe}_{2} \mathrm{O}_{3}$ & $\mathrm{MnO}$ & $\mathrm{MgO}$ & $\mathrm{CaO}$ & $\mathrm{Na}_{2} \mathrm{O}$ & $\mathrm{K}_{2} \mathrm{O}$ & $\mathrm{P}_{2} \mathrm{O}_{5}$ & $\mathrm{Sr}$ & $\mathrm{Zr}$ & $\mathrm{Cu}$ & $\mathrm{Cr}$ & $\mathrm{V}$ & $\mathrm{Y}$ & $\mathrm{Ni}$ & $\mathrm{Sc}$ & $\mathrm{Ba}$ \\
\hline \multicolumn{21}{|l|}{$\overline{\text { IODP U1433B }}$} \\
\hline $63 \mathrm{R}-1,39-43 \mathrm{~cm}$ & 14.80 & 55.86 & 0.65 & 17.92 & 8.00 & 0.09 & 2.35 & 0.48 & 0.83 & 3.13 & 0.09 & 206.7 & 123 & 62.7 & 76.9 & 163 & 35.6 & 87.3 & 16.9 & 999 \\
\hline $63 \mathrm{R}-4,112-116 \mathrm{~cm}$ & 15.01 & 57.84 & 0.64 & 16.58 & 8.57 & 0.17 & 2.39 & 0.52 & 0.92 & 3.15 & 0.08 & 182.3 & 128 & 82.7 & 77.5 & 113 & 41.5 & 63.8 & 16.2 & 1096 \\
\hline $64 \mathrm{R}-1,50-54 \mathrm{~cm}$ & 15.03 & 55.99 & 0.58 & 14.61 & 9.49 & 0.35 & 2.90 & 0.71 & 0.81 & 2.83 & 0.09 & 189.5 & 113 & 97.3 & 67.0 & 201 & 43.8 & 108.4 & 15.5 & 2229 \\
\hline $65 \mathrm{R}-1,57-61 \mathrm{~cm}$ & 17.29 & 51.93 & 0.62 & 15.62 & 10.60 & 1.63 & 3.15 & 0.69 & 0.48 & 3.36 & 0.08 & 198.0 & 112 & 311.0 & 73.7 & 126 & 38.6 & 133.3 & 15.9 & 717 \\
\hline
\end{tabular}




\begin{tabular}{|c|c|c|c|c|c|c|c|}
\hline Sample & $\begin{array}{l}\text { Age } \\
(\mathrm{Ma})\end{array}$ & $\begin{array}{c}\text { Smectite } \\
(\%)\end{array}$ & $\begin{array}{c}\text { Chlorite } \\
(\%)\end{array}$ & $\begin{array}{l}\text { Illite } \\
(\%)\end{array}$ & $\begin{array}{c}\text { Kaolinite } \\
(\%)\end{array}$ & $\begin{array}{c}\text { Illite } \\
\text { Crystallinity } \\
\end{array}$ & $\begin{array}{c}\text { Illite } \\
\text { Chemistry } \\
\text { Index }\end{array}$ \\
\hline \multicolumn{8}{|l|}{ IODP U1433A } \\
\hline $1 \mathrm{H}-1,50-52 \mathrm{~cm}$ & 0.00 & 23.2 & 20.8 & 39.6 & 16.3 & 0.243 & 0.406 \\
\hline $1 \mathrm{H}-3,50-52 \mathrm{~cm}$ & 0.01 & 26.2 & 20.1 & 40.2 & 13.5 & 0.222 & 0.353 \\
\hline $6 \mathrm{H}-5,60-64 \mathrm{~cm}$ & 0.10 & 17.1 & 22.3 & 43.0 & 17.6 & 0.278 & 0.408 \\
\hline $11 \mathrm{H}-1,50-52 \mathrm{~cm}$ & 0.34 & 17.1 & 21.5 & 43.4 & 18.0 & 0.268 & 0.378 \\
\hline $13 \mathrm{H}-1,50-54 \mathrm{~cm}$ & 0.41 & 29.3 & 19.6 & 37.7 & 13.4 & 0.238 & 0.406 \\
\hline $14 \mathrm{H}-5,50-54 \mathrm{~cm}$ & 0.50 & 14.2 & 26.1 & 44.0 & 15.6 & 0.230 & 0.411 \\
\hline $16 \mathrm{H}-1,50-54 \mathrm{~cm}$ & 0.62 & 22.4 & 21.6 & 42.6 & 13.4 & 0.245 & 0.379 \\
\hline $16 \mathrm{H}-3,50-54 \mathrm{~cm}$ & 0.63 & 23.1 & 21.1 & 39.7 & 16.1 & 0.251 & 0.400 \\
\hline $17 \mathrm{H}-5,50-54 \mathrm{~cm}$ & 0.71 & 16.4 & 22.5 & 42.6 & 18.5 & 0.252 & 0.408 \\
\hline $19 \mathrm{H}-1,50-52 \mathrm{~cm}$ & 0.79 & 23.2 & 20.4 & 39.7 & 16.7 & 0.238 & 0.391 \\
\hline \multicolumn{8}{|l|}{ IODP U1433B } \\
\hline $2 \mathrm{R}-1,34-36 \mathrm{~cm}$ & 0.90 & 13.4 & 23.1 & 46.6 & 16.9 & 0.233 & 0.347 \\
\hline $2 \mathrm{R}-1,85-87 \mathrm{~cm}$ & 0.90 & 10.0 & 22.9 & 44.9 & 22.2 & 0.280 & 0.385 \\
\hline $4 \mathrm{R}-1,24-28 \mathrm{~cm}$ & 1.01 & 21.7 & 22.2 & 40.4 & 15.7 & 0.242 & 0.377 \\
\hline $5 \mathrm{R}-5,60-64 \mathrm{~cm}$ & 1.23 & 24.5 & 22.7 & 40.5 & 12.4 & 0.254 & 0.369 \\
\hline $6 \mathrm{R}-2,100-104 \mathrm{~cm}$ & 1.47 & 13.3 & 24.4 & 43.3 & 19.0 & 0.265 & 0.394 \\
\hline $6 \mathrm{R}-4,30-34 \mathrm{~cm}$ & 1.57 & 18.0 & 23.5 & 43.2 & 15.3 & 0.251 & 0.393 \\
\hline $8 \mathrm{R}-2,110-114 \mathrm{~cm}$ & 1.71 & 39.1 & 16.6 & 33.8 & 10.5 & 0.233 & 0.377 \\
\hline $8 \mathrm{R}-5,50-54 \mathrm{~cm}$ & 1.73 & 27.0 & 20.7 & 39.2 & 13.1 & 0.236 & 0.381 \\
\hline $10 \mathrm{R}-3,50-54 \mathrm{~cm}$ & 1.91 & 48.7 & 14.4 & 25.7 & 11.3 & 0.246 & 0.372 \\
\hline $12 \mathrm{R}-1,36-38 \mathrm{~cm}$ & 2.05 & 50.3 & 12.2 & 28.1 & 9.4 & 0.235 & 0.340 \\
\hline $12 \mathrm{R}-4,53-55 \mathrm{~cm}$ & 2.08 & 41.2 & 16.3 & 31.8 & 10.8 & 0.240 & 0.405 \\
\hline $13 \mathrm{R}-1,78-82 \mathrm{~cm}$ & 2.13 & 19.7 & 21.8 & 41.3 & 17.2 & 0.249 & 0.379 \\
\hline $15 \mathrm{R}-3,60-64 \mathrm{~cm}$ & 2.30 & 32.0 & 18.3 & 35.3 & 14.4 & 0.247 & 0.425 \\
\hline $16 \mathrm{R}-4,110-114 \mathrm{~cm}$ & 2.39 & 26.4 & 17.7 & 36.7 & 19.1 & 0.249 & 0.378 \\
\hline $17 \mathrm{R}-3,100-104 \mathrm{~cm}$ & 2.46 & 26.0 & 19.1 & 35.9 & 19.0 & 0.240 & 0.384 \\
\hline $17 \mathrm{R}-5,114-118 \mathrm{~cm}$ & 2.48 & 28.8 & 19.1 & 36.8 & 15.3 & 0.241 & 0.377 \\
\hline $18 \mathrm{R}-2,100-104 \mathrm{~cm}$ & 2.59 & 30.1 & 19.0 & 34.7 & 16.2 & 0.252 & 0.441 \\
\hline $18 \mathrm{R}-4,50-54 \mathrm{~cm}$ & 2.65 & 26.3 & 20.5 & 37.2 & 16.0 & 0.228 & 0.370 \\
\hline $19 \mathrm{R} 3,71-75 \mathrm{~cm}$ & 2.88 & 30.6 & 18.0 & 32.6 & 18.7 & 0.255 & 0.380 \\
\hline $19 \mathrm{R}-5,55-59 \mathrm{~cm}$ & 2.95 & 40.0 & 15.2 & 28.0 & 16.9 & 0.223 & 0.360 \\
\hline $20 \mathrm{R}-4,90-94 \mathrm{~cm}$ & 3.18 & 28.9 & 19.6 & 34.8 & 16.6 & 0.227 & 0.399 \\
\hline $20 \mathrm{R}-6,40-44 \mathrm{~cm}$ & 3.25 & 36.9 & 17.8 & 33.5 & 11.7 & 0.220 & 0.393 \\
\hline $21 \mathrm{R}-3,141-143 \mathrm{~cm}$ & 3.42 & 39.2 & 15.4 & 31.4 & 14.0 & 0.216 & 0.376 \\
\hline $22 \mathrm{R}-1,23-25 \mathrm{~cm}$ & 3.54 & 26.0 & 19.3 & 35.1 & 19.6 & 0.206 & 0.411 \\
\hline $23 \mathrm{R}-3,145-149 \mathrm{~cm}$ & 3.60 & 32.8 & 17.3 & 31.4 & 18.5 & 0.241 & 0.402 \\
\hline $25 \mathrm{R}-5,55-59 \mathrm{~cm}$ & 3.69 & 26.7 & 19.7 & 34.1 & 19.5 & 0.224 & 0.401 \\
\hline $26 \mathrm{R}-1,50-54 \mathrm{~cm}$ & 3.80 & 24.0 & 19.6 & 36.1 & 20.3 & 0.220 & 0.403 \\
\hline $26 \mathrm{R}-3,50-54 \mathrm{~cm}$ & 3.96 & 32.7 & 18.8 & 33.3 & 15.2 & 0.247 & 0.359 \\
\hline $26 \mathrm{R}-5,50-54 \mathrm{~cm}$ & 4.11 & 39.7 & 15.6 & 29.3 & 15.3 & 0.242 & 0.371 \\
\hline
\end{tabular}

Liu et al. 


\begin{tabular}{|c|c|c|c|c|c|c|c|}
\hline Sample & $\begin{array}{l}\text { Age } \\
(\mathrm{Ma})\end{array}$ & $\begin{array}{l}\text { Smectite } \\
(\%)\end{array}$ & $\begin{array}{c}\text { Chlorite } \\
(\%)\end{array}$ & $\begin{array}{l}\text { Illite } \\
(\%)\end{array}$ & $\begin{array}{c}\text { Kaolinite } \\
(\%)\end{array}$ & $\begin{array}{c}\text { Illite } \\
\text { Crystallinity }\end{array}$ & $\begin{array}{c}\text { Illite } \\
\text { Chemistry } \\
\text { Index }\end{array}$ \\
\hline \multicolumn{8}{|l|}{ IODP U1433B } \\
\hline $27 \mathrm{R}-1,40-44 \mathrm{~cm}$ & 4.33 & 36.0 & 16.4 & 32.2 & 15.3 & 0.224 & 0.387 \\
\hline $27 \mathrm{R}-2,15-19 \mathrm{~cm}$ & 4.36 & 45.5 & 13.1 & 33.0 & 8.3 & 0.192 & 0.345 \\
\hline $28 \mathrm{R}-1,62-66 \mathrm{~cm}$ & 4.80 & 35.4 & 17.1 & 33.5 & 14.0 & 0.215 & 0.382 \\
\hline $28 \mathrm{R}-3,48-52 \mathrm{~cm}$ & 4.92 & 19.9 & 21.6 & 37.2 & 21.3 & 0.240 & 0.396 \\
\hline $29 \mathrm{R}-1,20-24 \mathrm{~cm}$ & 5.14 & 45.6 & 16.5 & 29.6 & 8.3 & 0.207 & 0.380 \\
\hline $29 \mathrm{R}-1,71-75 \mathrm{~cm}$ & 5.15 & 45.0 & 13.9 & 31.3 & 9.7 & 0.223 & 0.366 \\
\hline $31 \mathrm{R}-1,50-52 \mathrm{~cm}$ & 5.30 & 25.3 & 19.5 & 36.3 & 19.0 & 0.238 & 0.383 \\
\hline $33 \mathrm{R}-1,101-103 \mathrm{~cm}$ & 5.34 & 31.3 & 17.7 & 37.5 & 13.5 & 0.220 & 0.395 \\
\hline $33 \mathrm{R}-5,106-108 \mathrm{~cm}$ & 5.35 & 35.2 & 16.4 & 36.9 & 11.5 & 0.222 & 0.377 \\
\hline $34 \mathrm{R}-1,26-28 \mathrm{~cm}$ & 5.67 & 42.3 & 15.1 & 31.3 & 11.3 & 0.221 & 0.355 \\
\hline $34 \mathrm{R}-3,26-28 \mathrm{~cm}$ & 5.85 & 33.1 & 16.2 & 34.7 & 16.0 & 0.232 & 0.398 \\
\hline $35 \mathrm{R}-1,39-41 \mathrm{~cm}$ & 6.08 & 38.6 & 16.2 & 31.9 & 13.3 & 0.231 & 0.384 \\
\hline $35 \mathrm{R}-3,46-48 \mathrm{~cm}$ & 6.12 & 31.7 & 17.9 & 34.8 & 15.6 & 0.228 & 0.395 \\
\hline $36 \mathrm{R}-1,40-44 \mathrm{~cm}$ & 6.31 & 22.3 & 22.2 & 37.9 & 17.6 & 0.223 & 0.429 \\
\hline $36 \mathrm{R}-3,48-52 \mathrm{~cm}$ & 6.38 & 22.6 & 19.6 & 39.2 & 18.6 & 0.241 & 0.384 \\
\hline $37 \mathrm{R}-3,78-82 \mathrm{~cm}$ & 6.61 & 16.2 & 24.2 & 39.0 & 20.6 & 0.215 & 0.418 \\
\hline $37 \mathrm{R}-5,78-82 \mathrm{~cm}$ & 6.68 & 24.3 & 21.1 & 35.5 & 19.1 & 0.233 & 0.430 \\
\hline $38 \mathrm{R}-3,94-98 \mathrm{~cm}$ & 6.86 & 23.1 & 20.9 & 37.8 & 18.2 & 0.233 & 0.391 \\
\hline $39 \mathrm{R}-1,78-82 \mathrm{~cm}$ & 7.02 & 35.7 & 16.8 & 35.4 & 12.1 & 0.215 & 0.409 \\
\hline 39R-6, 66-69 cm & 7.17 & 60.2 & 10.6 & 21.0 & 8.2 & 0.190 & 0.397 \\
\hline $40 \mathrm{R}-5,49-53 \mathrm{~cm}$ & 7.38 & 32.8 & 17.9 & 34.1 & 15.2 & 0.205 & 0.426 \\
\hline $40 \mathrm{R}-6,5-9 \mathrm{~cm}$ & 7.39 & 27.1 & 19.6 & 36.1 & 17.2 & 0.222 & 0.392 \\
\hline $43 \mathrm{R}-2,119-122 \mathrm{~cm}$ & 7.51 & 54.9 & 11.9 & 23.6 & 9.6 & 0.231 & 0.380 \\
\hline $44 \mathrm{R}-3,63-65 \mathrm{~cm}$ & 7.56 & 34.0 & 18.9 & 34.5 & 12.6 & 0.213 & 0.371 \\
\hline $44 \mathrm{R}-5,48-50 \mathrm{~cm}$ & 7.58 & 55.4 & 10.9 & 23.0 & 10.7 & 0.235 & 0.387 \\
\hline $45 \mathrm{R}-1,34-38 \mathrm{~cm}$ & 7.61 & 33.3 & 18.3 & 34.6 & 13.8 & 0.221 & 0.380 \\
\hline $45 \mathrm{R}-3,89-93 \mathrm{~cm}$ & 7.63 & 30.3 & 18.4 & 35.0 & 16.3 & 0.233 & 0.434 \\
\hline $46 \mathrm{R}-2,86-90 \mathrm{~cm}$ & 7.69 & 43.8 & 15.5 & 29.7 & 11.0 & 0.228 & 0.409 \\
\hline $48 \mathrm{R}-1,103-107 \mathrm{~cm}$ & 7.82 & 67.4 & 8.0 & 18.3 & 6.4 & 0.224 & 0.429 \\
\hline $49 \mathrm{R}-3,61-65 \mathrm{~cm}$ & 7.91 & 37.1 & 15.0 & 34.2 & 13.6 & 0.312 & 0.376 \\
\hline $51 \mathrm{R}-1,35-38 \mathrm{~cm}$ & 8.02 & 40.7 & 15.3 & 30.6 & 13.4 & 0.213 & 0.388 \\
\hline $52 \mathrm{R}-1,118-121 \mathrm{~cm}$ & 8.10 & 24.9 & 20.3 & 35.2 & 19.6 & 0.263 & 0.447 \\
\hline $53 \mathrm{R}-1,40-42 \mathrm{~cm}$ & 8.16 & 31.7 & 20.1 & 34.2 & 13.9 & 0.251 & 0.425 \\
\hline $54 \mathrm{R}-2,133-137 \mathrm{~cm}$ & 8.25 & 49.8 & 11.2 & 33.3 & 5.8 & 0.319 & 0.382 \\
\hline $54 \mathrm{R}-5,85-89 \mathrm{~cm}$ & 8.27 & 66.5 & 6.9 & 18.9 & 7.6 & 0.250 & 0.331 \\
\hline $55 \mathrm{R}-3,88-90 \mathrm{~cm}$ & 8.76 & 52.0 & 11.2 & 30.5 & 6.3 & 0.217 & 0.304 \\
\hline $55 \mathrm{R}-4,98-100 \mathrm{~cm}$ & 8.94 & 65.2 & 10.6 & 19.4 & 4.8 & 0.220 & 0.360 \\
\hline $55 \mathrm{R}-5,60-62 \mathrm{~cm}$ & 9.07 & 78.7 & 4.0 & 12.7 & 4.6 & 0.229 & 0.324 \\
\hline $56 \mathrm{R}-1,80-84 \mathrm{~cm}$ & 9.60 & 48.3 & 12.7 & 28.3 & 10.7 & 0.231 & 0.384 \\
\hline $57 \mathrm{R}-6,85-89 \mathrm{~cm}$ & 10.99 & 69.1 & 7.0 & 18.0 & 5.9 & 0.224 & 0.342 \\
\hline $58 \mathrm{R}-1,37-41 \mathrm{~cm}$ & 11.12 & 75.0 & 3.5 & 15.0 & 6.6 & 0.226 & 0.357 \\
\hline
\end{tabular}

Liu et al. 
Table 2

\begin{tabular}{|c|c|c|c|c|c|c|c|}
\hline Sample & $\begin{array}{l}\text { Age } \\
(\mathrm{Ma})\end{array}$ & $\begin{array}{c}\text { Smectite } \\
(\%)\end{array}$ & $\begin{array}{c}\text { Chlorite } \\
(\%)\end{array}$ & $\begin{array}{c}\text { Illite } \\
(\%)\end{array}$ & $\begin{array}{c}\text { Kaolinite } \\
(\%)\end{array}$ & $\begin{array}{c}\text { Illite } \\
\text { Crystallinity } \\
\end{array}$ & $\begin{array}{c}\text { Illite } \\
\text { Chemistry } \\
\text { Index } \\
\end{array}$ \\
\hline \multicolumn{8}{|l|}{ IODP U1433B } \\
\hline $58 \mathrm{R}-2,73-77 \mathrm{~cm}$ & 11.26 & 60.4 & 8.7 & 26.2 & 4.7 & 0.327 & 0.385 \\
\hline $58 \mathrm{R}-6,91-95 \mathrm{~cm}$ & 11.73 & 89.1 & 1.9 & 8.0 & 1.0 & 0.262 & 0.355 \\
\hline $59 \mathrm{R}-3,59-61 \mathrm{~cm}$ & 12.09 & 86.0 & 2.5 & 10.1 & 1.5 & 0.224 & 0.355 \\
\hline $59 \mathrm{R}-4,130-133 \mathrm{~cm}$ & 12.26 & 40.5 & 15.0 & 37.7 & 6.7 & 0.359 & 0.321 \\
\hline $60 \mathrm{R}-2,45-47 \mathrm{~cm}$ & 12.71 & 29.9 & 18.4 & 41.4 & 10.3 & 0.350 & 0.380 \\
\hline $60 \mathrm{R}-4,74-76 \mathrm{~cm}$ & 12.95 & 55.8 & 9.2 & 32.0 & 3.1 & 0.300 & 0.305 \\
\hline $60 \mathrm{R}-6,37-39 \mathrm{~cm}$ & 13.15 & 53.3 & 10.4 & 25.5 & 10.8 & 0.243 & 0.357 \\
\hline $61 \mathrm{R}-1,102-104 \mathrm{~cm}$ & 13.37 & 46.8 & 12.3 & 32.2 & 8.8 & 0.241 & 0.357 \\
\hline $61 \mathrm{R}-2,131-135 \mathrm{~cm}$ & 13.50 & 80.1 & 4.6 & 10.6 & 4.7 & 0.284 & 0.399 \\
\hline $61 \mathrm{R}-4,39-43 \mathrm{~cm}$ & 13.66 & 55.0 & 9.3 & 26.8 & 8.9 & 0.248 & 0.317 \\
\hline $62 \mathrm{R}-1,112-116 \mathrm{~cm}$ & 14.12 & 52.2 & 10.1 & 28.4 & 9.4 & 0.247 & 0.397 \\
\hline $62 \mathrm{R}-3,113-117 \mathrm{~cm}$ & 14.35 & 61.3 & 8.4 & 23.8 & 6.6 & 0.246 & 0.329 \\
\hline $62 \mathrm{R}-5,119-123 \mathrm{~cm}$ & 14.58 & 84.0 & 2.8 & 10.7 & 2.5 & 0.238 & 0.293 \\
\hline $63 \mathrm{R}-1,39-43 \mathrm{~cm}$ & 14.80 & 70.7 & 6.9 & 17.0 & 5.4 & 0.248 & 0.315 \\
\hline $63 \mathrm{R}-4,112-116 \mathrm{~cm}$ & 15.01 & 66.3 & 2.4 & 23.0 & 8.3 & 0.272 & 0.376 \\
\hline $64 \mathrm{R}-1,50-54 \mathrm{~cm}$ & 15.03 & 71.2 & 6.9 & 17.9 & 4.0 & 0.276 & 0.402 \\
\hline $65 \mathrm{R}-1,57-61 \mathrm{~cm}$ & 17.29 & 56.2 & 12.4 & 23.6 & 7.9 & 0.231 & 0.396 \\
\hline
\end{tabular}

Liu et al. 
Table 3

\begin{tabular}{|c|c|c|c|c|}
\hline Sample & $\begin{array}{l}\text { Age } \\
(\mathrm{Ma})\end{array}$ & ${ }^{87} \mathrm{Sr} /{ }^{86} \mathrm{Sr}$ & ${ }^{143} \mathrm{Nd} /{ }^{144} \mathrm{Nd}$ & Epsilon $\mathrm{Nd}$ \\
\hline \multicolumn{5}{|l|}{ IODP U1433A } \\
\hline $1 \mathrm{H}-3,50-52 \mathrm{~cm}$ & 0.01 & 0.723270 & 0.512070 & -11.1 \\
\hline $16 \mathrm{H}-1,50-54 \mathrm{~cm}$ & 0.62 & 0.726637 & 0.512068 & -11.1 \\
\hline \multicolumn{5}{|l|}{ IODP U1433B } \\
\hline $5 \mathrm{R}-5,60-64 \mathrm{~cm}$ & 1.23 & 0.728032 & 0.512057 & -11.3 \\
\hline $8 \mathrm{R}-5,50-54 \mathrm{~cm}$ & 1.73 & 0.724873 & 0.512093 & -10.6 \\
\hline $15 \mathrm{R}-3,60-64 \mathrm{~cm}$ & 2.30 & 0.728157 & 0.512070 & -11.1 \\
\hline $19 \mathrm{R}-5,55-59 \mathrm{~cm}$ & 2.95 & 0.727383 & 0.512039 & -11.7 \\
\hline $20 \mathrm{R}-6,40-44 \mathrm{~cm}$ & 3.25 & 0.725789 & 0.512085 & -10.8 \\
\hline $26 \mathrm{R}-1,50-54 \mathrm{~cm}$ & 3.80 & 0.729998 & 0.512050 & -11.5 \\
\hline $26 \mathrm{R}-5,50-54 \mathrm{~cm}$ & 4.11 & 0.726594 & 0.512083 & -10.8 \\
\hline $28 \mathrm{R}-1,62-66 \mathrm{~cm}$ & 4.80 & 0.723252 & 0.512109 & -10.3 \\
\hline $33 \mathrm{R}-5,106-108 \mathrm{~cm}$ & 5.35 & 0.723778 & 0.512152 & -9.5 \\
\hline $35 \mathrm{R}-1,39-41 \mathrm{~cm}$ & 6.08 & 0.729627 & 0.512055 & -11.4 \\
\hline $37 \mathrm{R}-3,78-82 \mathrm{~cm}$ & 6.61 & 0.730936 & 0.512036 & -11.7 \\
\hline $40 \mathrm{R}-5,49-53 \mathrm{~cm}$ & 7.38 & 0.730567 & 0.512034 & -11.8 \\
\hline $40 \mathrm{R}-5,49-53 \mathrm{~cm}$ & 7.38 & 0.730525 & 0.512023 & -12.0 \\
\hline $40 \mathrm{R}-5,49-53 \mathrm{~cm}$ & 7.38 & & 0.512036 & -11.7 \\
\hline $51 \mathrm{R}-1,35-38 \mathrm{~cm}$ & 8.02 & 0.730567 & 0.512025 & -12.0 \\
\hline $54 \mathrm{R}-5,85-89 \mathrm{~cm}$ & 8.27 & 0.718308 & 0.512090 & -10.7 \\
\hline $55 \mathrm{R}-3,88-90 \mathrm{~cm}$ & 8.76 & 0.717633 & 0.512116 & -10.2 \\
\hline $55 \mathrm{R}-5,60-62 \mathrm{~cm}$ & 9.07 & 0.716482 & 0.512205 & -8.4 \\
\hline $56 \mathrm{R}-1,80-84 \mathrm{~cm}$ & 9.60 & 0.719418 & 0.512132 & -9.9 \\
\hline $57 \mathrm{R}-2,67-70 \mathrm{~cm}$ & 10.52 & 0.712584 & 0.512231 & -7.9 \\
\hline $57 \mathrm{R}-6,85-89 \mathrm{~cm}$ & 10.99 & 0.721065 & 0.512143 & -9.7 \\
\hline $58 \mathrm{R}-2,73-77 \mathrm{~cm}$ & 11.26 & 0.716830 & 0.512276 & -7.1 \\
\hline $58 \mathrm{R}-6,91-95 \mathrm{~cm}$ & 11.73 & 0.715851 & 0.512309 & -6.4 \\
\hline 59R-4, 130-133 cm & 12.26 & 0.717045 & 0.512302 & -6.6 \\
\hline $60 \mathrm{R}-2,45-47 \mathrm{~cm}$ & 12.71 & 0.718080 & 0.512262 & -7.3 \\
\hline $60 \mathrm{R}-6,37-39 \mathrm{~cm}$ & 13.15 & 0.721289 & 0.512144 & -9.6 \\
\hline $61 \mathrm{R}-1,102-104 \mathrm{~cm}$ & 13.37 & 0.715412 & 0.512194 & -8.7 \\
\hline $61 \mathrm{R}-4,39-43 \mathrm{~cm}$ & 13.66 & 0.718294 & 0.512138 & -9.8 \\
\hline $61 \mathrm{R}-4,39-43 \mathrm{~cm}$ & 14.66 & 0.718332 & 0.512147 & -9.6 \\
\hline $61 \mathrm{R}-4,39-43 \mathrm{~cm}$ & 15.66 & & 0.512139 & -9.7 \\
\hline $62 \mathrm{R}-1,112-116 \mathrm{~cm}$ & 14.12 & 0.716304 & 0.512170 & -9.1 \\
\hline $62 \mathrm{R}-5,119-123 \mathrm{~cm}$ & 14.58 & 0.709552 & 0.512360 & -5.4 \\
\hline $64 \mathrm{R}-1,50-54 \mathrm{~cm}$ & 15.03 & 0.712963 & 0.512312 & -6.4 \\
\hline $65 \mathrm{R}-1,57-61 \mathrm{~cm}$ & 17.29 & 0.717409 & 0.512235 & -7.9 \\
\hline
\end{tabular}

Liu et al. 


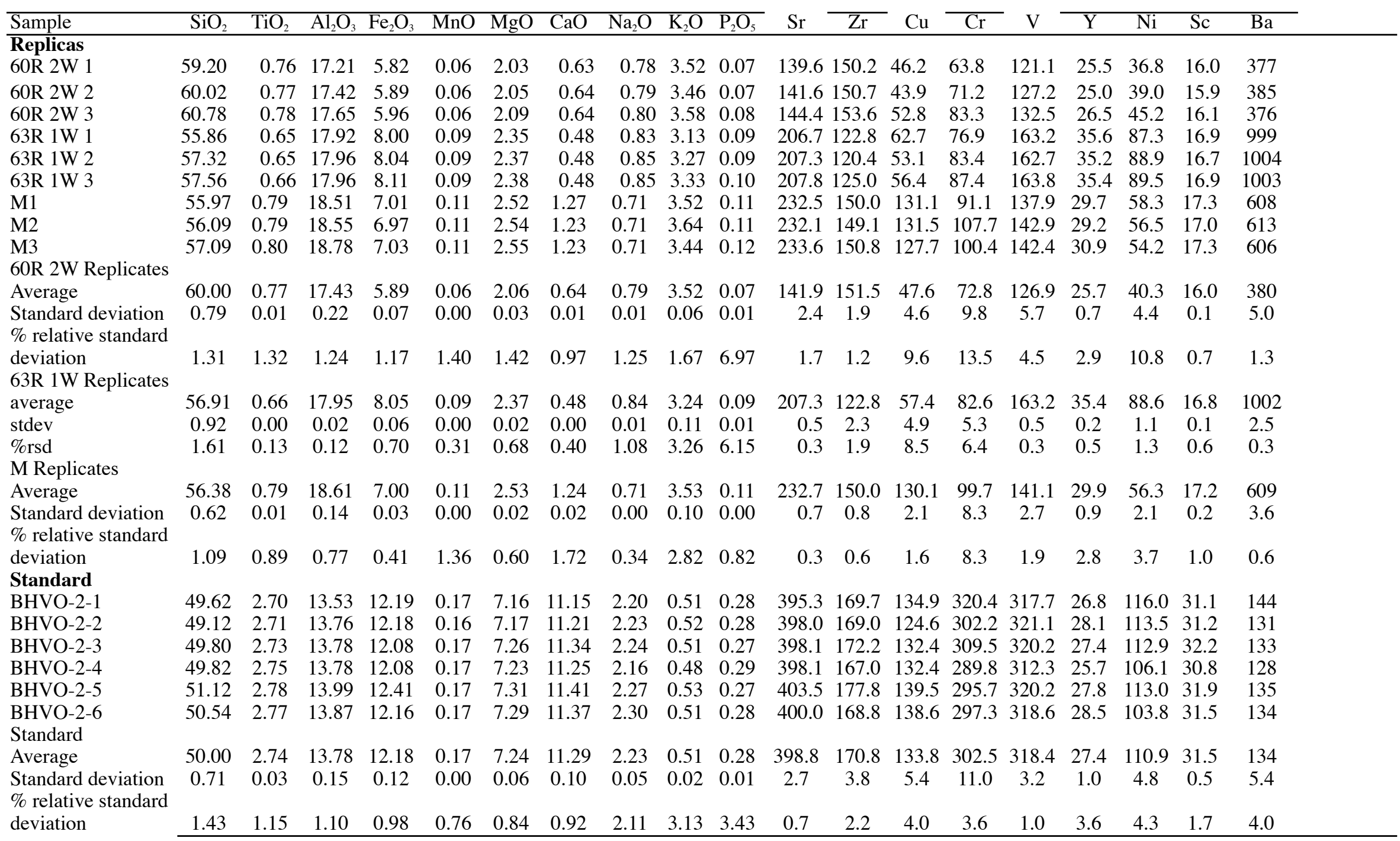

Liu et al. 
Click here to download Background dataset for online publication only: Table_S1_U1433_Geochemical Data_suplimental materi

Background dataset for online publication only
Click here to download Background dataset for

1_ U1433_Geochemical Data_suplimental materi (1) 